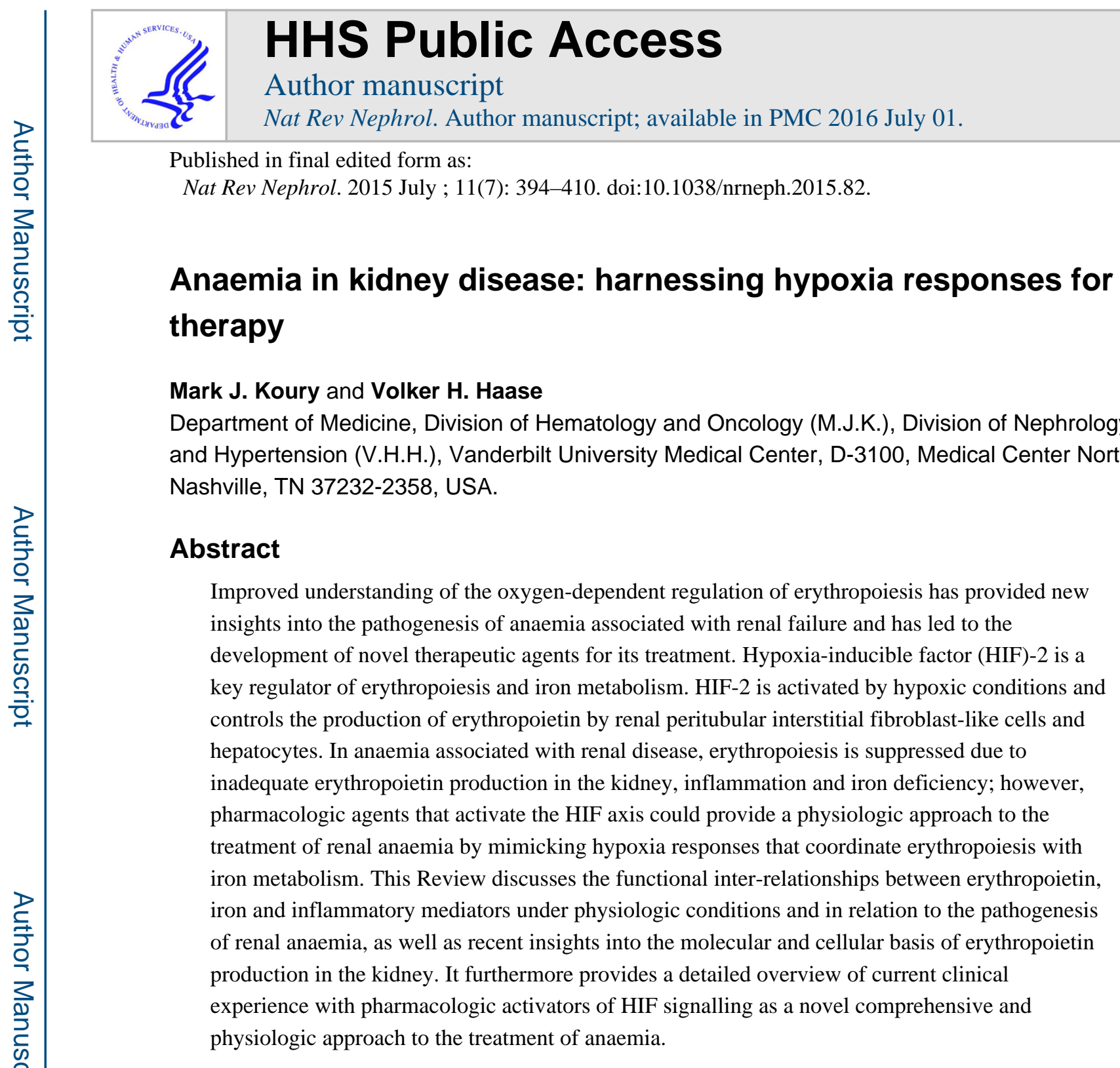

\title{
Introduction
}

Anaemia is a clinical hallmark of advanced kidney disease that is characterized by decreased levels of haemoglobin and haematocrit, and decreased numbers of circulating erythrocytes. Decreased erythrocyte numbers occur when fewer new erythrocytes enter the circulation than are lost or destroyed. In anaemia associated with renal failure, this decrease is rarely caused directly by increased rates of erythrocyte loss or destruction. Rather, it is caused by insufficient erythropoiesis to replace the $2 \times 10^{11}$ senescent erythrocytes that are removed

Correspondence to: V.H.H. volker.haase@ vanderbilt.edu.

Competing interests

M.J.K. is a consultant for Keryx Biopharmaceuticals, Inc. V.H.H. has received honoraria from Daiichi Sankyo and serves on the Scientific Advisory Board of Akebia Therapeutics, a company that develops prolyl-4-hydroxylase inhibitors for the treatment of renal anaemia.

Author contributions M.J.K. and V.H.H. contributed equally to writing the article and to review and/or editing of the manuscript before submission.

Supplementary information is linked to the online version of the paper at www.nature.com/nrneph. 
from the circulation on a daily basis under physiologic conditions. Haemoglobin, the major iron-containing erythrocyte protein, transports oxygen from the lungs to other tissues to enable cellular respiration. In anaemia, decreased oxygen transport causes tissue hypoxia, which through activation of the hypoxia-inducible factor (HIF) system stimulates the production of erythropoietin, the principal hormonal regulator of erythropoiesis. This classic hypoxia response is greatly impaired in patients with kidney failure, as the kidney is the major site of erythropoietin production under physiologic and hypoxic conditions. Although therapy with recombinant human erythropoietin (rhEPO) alleviates renal erythropoietin deficiency, this approach has revealed iron deficiency and chronic inflammation to be additional important factors in the pathogenesis of anaemia associated with renal failure.

This Review includes novel mechanistic insights into the hypoxic regulation of erythropoiesis and renal erythropoietin production, and describes the newly discovered interrelationships between erythropoietin synthesis, erythrocyte production, iron metabolism and chronic inflammation. The current clinical experience with pharmacologic HIF activators as an emerging physiologic approach to the treatment of renal anaemia is also discussed in detail.

\section{Regulation of erythropoiesis}

Erythroid differentiation-Erythropoiesis occurs mainly in the bone marrow, and involves the differentiation of erythroid progenitor cells from haematopoietic stem cells (HSCs). In a series of steps regulated by the transcription factors PU.1 and GATA1, HSCs and their progeny lose the ability to differentiate into cells of the lymphoid and granulocytic-monocytic lineages, and instead become bipotent megakaryocytic- erythroid progenitors (MEPs) (Figure 1a). Increased activity of erythroid Krüppel-like transcription factor (KLF1) promotes differentiation of MEPs ${ }^{1,2}$ toward the most immature erythroid progenitors, burst-forming units-erythroid (BFU-Es), ${ }^{3}$ which in culture, produce large colonies of human erythroblasts. The next stage of erythroid progenitor cells, colonyforming units-erythroid (CFU-Es), ${ }^{3}$ and their progeny, the erythroblasts, adhere to a central macrophage, forming an erythroblastic island - the marrow niche of terminal erythropoiesis (Figure 1b). ${ }^{4}$ Erythroblastic islands are the sites of cells at different stages of erythroblast differentiation, including proerythroblasts, basophilic erythroblasts, polychromatophilic erythroblasts and orthochromatic erythroblasts (Figure 1). Orthochromatic erythroblasts enucleate to form reticulocytes, which are irregularly shaped cells that contain haemoglobin and residual organelles (the reticulum), distinguishing them from mature erythrocytes. The extruded nuclei are rapidly phagocytosed by central macro phages, which degrade the nuclei and the small amount of haemoglobin that is associated with each extruded nucleus, and recycle nucleosides and iron. ${ }^{5}$ Reticulocytes enter the circulation, lose their residual internal organelles via autophagy, and transform into uniform, biconcave discoid erythrocytes through microvesicle exocytosis. ${ }^{6}$ The maturation of reticulocytes to erythrocytes usually takes 1-2 days from the reticulocyte entering the circulation, but erythrocytes continually shed low numbers of microvesicles for another 110-120 days, after which they become senes-cent and are phagocytosed by splenic, hepatic or bone marrow macrophages. ${ }^{7}$ 
Haemoglobin synthesis-Haemoglobin synthesis begins in late basophilic erythroblasts and continues through to reticulocyte maturation (Figure 1). During haemoglobin production, large quantities of iron are imported into erythroblasts, but this iron is directed towards haeme synthesis, with little intracellular accumulation of iron or protoporphyrin. Large amounts of haeme produced in erythroblasts are promptly incorporated into haemoglobin with no accumulation of excess globin chains or haeme. ${ }^{8}$ Intracellular iron and haeme control haemoglobin synthesis in erythroblasts through multiple mechanisms including the haeme-regulated acquisition of iron from endocytosed transferrin receptors; ${ }^{9}$ the regulation of haeme synthesis by iron via activation of a 5 ' iron-responsive element in erythroid-specific 5-aminolevulinic acid synthase (ALAS2) to control the first step of haeme synthesis; ${ }^{9}$ the regulation of erythroblast protein synthesis by haeme through inactivation of haeme-regulated eIF2a kinase (also known as haeme-regulated inhibitor; HRI), which phosphorylates the translation initiation factor eIF $2 a$ and prevents initiation of translation; ${ }^{10}$ and induction of $\beta$-globin transcription by haeme, through the degradation of $\mathrm{BACH} 1$, a transcription repressor at the $\beta$-globin locus control region. ${ }^{11,12}$

Erythropoietin dependence and apoptosis-Within the erythroblastic island, CFUEs and proerythroblasts lose responsiveness to stem cell factor and insulin-like growth factor-1 supplied by the marrow environment ${ }^{13}$ and become dependent on erythropoietin, the principal regulator of erythropoiesis, for survival (Figure 1). In response to hypoxic stress, however, expansion of CFU-E and proerythroblast populations in the absence of differentiation is mediated by glucocorticoids, ${ }^{14,15}$ which induce a protein that binds mRNAs involved in terminal erythroid differentiation, ${ }^{16}$ and bone morphogenetic protein 4 (BMP4), ${ }^{17}$ which is produced by central macrophages. ${ }^{18}$ Binding of erythropoietin to specific transmembrane glycoprotein receptors (EPORs), which are expressed as homodimers ${ }^{19}$ on CFU-E, proerythroblasts and early basophilic erythroblasts ${ }^{20}$ leads to a series of events, including conform ational changes in EPORs, initiation of intracellular signalling by the EPORs and endocytosis of the erythropoietin-EPOR complexes, which are subsequently degraded. ${ }^{21,22}$ Endocytosis and intracellular degradation of erythropoietinEPOR complexes is a mechanism to metabolize circulating erythropoietin. ${ }^{23}$ EPORs lack intrinsic enzyme activity, but they can initiate signal transduction pathways through Janus Tyrosine Kinase-2 (JAK2), which physically associates with the cytoplasmic portion of EPORs and chaperones them to the surface of erythroid cells. ${ }^{24,25}$ Following activation and conformational changes in EPORs that result from erythropoietin binding, JAK2 autophos phorylates, phosphorylates EPORs, and initiates signalling through several pathways including signal transduction and activator of transcription-5 (STAT5), RAS-RAF-MAP kinase, and phosphoinositol-3 kinase/AKT kinase (protein kinase B). ${ }^{26}$

Erythropoietin-mediated signalling prevents apoptosis of CFU-Es, proerythroblasts and early basophilic erythroblasts. ${ }^{27-30}$ During this erythropoietin-dependent period, individual erythroid cells have markedly different erythropoietin requirements for survival. ${ }^{31}$ The varying susceptibility of erythropoietin-dependent erythroid progenitors to apoptosis is associated with varying expression levels of FAS (also known as CD95), a membrane protein of the tumour necrosis factor (TNF) receptor family, which triggers apoptosis after binding FAS ligand. ${ }^{32}$ Erythropoietin decreases expression of FAS on erythroid progenitors. 
Fas ligand is produced by various cell types, but in human erythroblastic islands, mature erythroblasts are major producers of Fas ligand. ${ }^{33}$ By contrast in mice, the erythropoietindependent, early-stage erythroblasts are themselves the major source of Fas ligand. ${ }^{34}$ Within the erythroblast populations, therefore, a negative feedback loop exists that is regulated by Fas ligand produced by mature erythroblasts in humans and by early erythroblasts in mice, which modulates the apoptotic rate of CFU-Es, proerythroblasts and early basophilic erythroblasts, and thereby affects the rate of erythrocyte production. ${ }^{32,34}$ Murine early erythroblasts, which both produce and respond to Fas ligand, provide a stabilizing effect on steady state erythrocyte production and enable the rapid splenic responses that characterize stress-induced erythropoiesis in mice. ${ }^{35}$ Based on the differences in erythroblast populations producing Fas ligand, simulations of erythrocyte recovery to baseline values following acute blood loss are consistent with a more protracted recovery observed in humans compared to mice. ${ }^{36}$ Of note, erythropoietin signalling also promotes the survival of erythroblasts in the post-erythropoietin-dependent period by inducing the anti-apoptotic protein $\mathrm{Bcl}-\mathrm{X}_{\mathrm{L}} \cdot{ }^{37,38}$

\section{The HIF oxygen sensing pathway}

Hypoxia is a classic stimulus of erythropoiesis, and the quest to unravel the molecular underpinnings of this response led to identification of erythropoietin and HIF transcription factors. HIFs are key mediators of a broad spectrum of cellular hypoxia responses and are essential for erythropoiesis under normal and hypoxic stress conditions. Lack of HIF in genetic mouse models results in anaemia, whereas impaired regulation of its activity results in erythrocytosis. ${ }^{39-43}$ Activating mutations in the HIF oxygen-sensing pathway have been identified in patients with previously unexplained polycythaemia. ${ }^{44}$ Moreover certain genetic variants are found in Tibetans, who are protected from chronic mountain sickness, a deadly condition that is associated with high altitude and is characterized by excessive polycythemia and right-sided heart failure. ${ }^{45,46}$

HIF transcription factors-HIF transcription factors are heterodimeric basic helix-loophelix proteins that belong to the PAS family of transcriptional regulators. They consist of an oxygen-sensitive $\alpha$-subunit and a constitutively expressed $\beta$-subunit, also known as the aryl hydrocarbon receptor nuclear trans-locator (ARNT) ${ }^{47-49}$ (Figure 2). Three HIF a-subunits have been identified-HIF-1a, HIF- $2 a$ and HIF-3a-however, investigations have largely focused on HIF-1a and HIF-2a, as these subunits have the most critical roles in the regulation of cellular hypoxia responses. Together, HIF-1 and HIF-2 facilitate oxygen delivery and cellular adaptation to hypoxia by controlling a broad spectrum of biological processes, which in addition to the regulation of erythropoiesis, include anaerobic metabolism, angio-genesis, mitochondrial metabolism, cellular growth and differentiation pathways. ${ }^{50} \mathrm{HIF}-$ mediated gene transcription is activated following DNA-binding and recruitment of transcriptional co-activators. ${ }^{49,51}$ Although HIF-1 and HIF-2 coregulate many genes, erythropoietin synthesis and iron metabolism are primarily regulated by HIF-2 in adults. ${ }^{40,41,43,52-55}$ The importance of HIF-2 in the regulation of erythropoiesis is underlined by mutations in patients with familial erythrocytosis. ${ }^{44}$

PHD-mediated HIF-adegradation-Cells continuously synthesize HIF-a subunits; therefore, control of the degradation rate is key to regulating HIF activity and erythropoiesis. 
Oxygen-dependent HIF degradation is initiated by three 2-oxoglutarate (2OG)-dependent oxygenases-prolyl-4-hydroxylase domain (PHD) proteins PHD1, PHD2 and PHD3 (also known as EGLN2, EGLN1 and EGLN3, respectively). These enzymes use molecular oxygen to hydroxylate HIF-a at specific proline residues (Pro402 and Pro564 in human HIF-1a; Pro405 and Pro531 in human HIF-2a) and belong to a larger family of proteins that couple the oxidative decarboxylation of $2 \mathrm{OG}$ to various chemical processes. ${ }^{56-63} \mathrm{PHD} 2$ is the main hydroxylase that regulates HIF activity under normoxia and inherited mutations in PHD2 that inhibit catalytic activity are associated with the development of erythrocytosis. ${ }^{64,65}$ Proline-hydroxylated HIF-a is rapidly degraded following ubiquity lation by the von Hippel-Lindau (VHL)-E3 ubiquitin ligase complex. Under conditions of hypoxia, hydroxylation is inhibited and HIF signalling is activated ${ }^{64}$ (Figure 2). A fourth putative HIF prolyl-hydroxylase, $\mathrm{P} 4 \mathrm{H}-\mathrm{TM}$, localizes to the endoplasmic reticulum and might be involved in the regulation of renal erythropoietin. ${ }^{66,67}$ In the kidney, which is the main physiologic source of systemic erythropoietin in adults, expression levels of PHD1, PHD2 and PHD3 vary between different cell types. ${ }^{68}$ Nevertheless, transcripts of all three PHDs have been detected in erythropoietin-producing cells isolated by fluorescenceactivated cell sorting. ${ }^{69}$ An additional mechanism of hypoxic regulation operates within the carboxy-terminal trans-activation domain of HIF-a, where factor inhibiting HIF (FIH) catalyses the hydroxylation of an asparagine residue, modulating co-activator recruitment and transcriptional activity of the HIF-heterodimers. ${ }^{64}$

\section{Hypoxic signalling: downstream effects}

The HIF pathway regulates and coordinates erythropoiesis at multiple levels by stimulating renal and hepatic erythropoietin production, promoting the uptake and utilization of iron, and altering the bone marrow microenvironment to facilitate erythroid progenitor maturation and proliferation (Figure 3). Improved understanding of these actions has led to the concept that pharmacologic activation of the HIF axis could provide a physiologic approach to the treatment of renal anaemia by mimicking hypoxia responses that coordinate erythropoiesis with iron metabolism.

Hypoxia regulated erythropoietin transcription-In kidney and liver, HIF-2 mediates the hypoxic induction of erythropoietin and binds to specific regulatory elements within the $E P O$ gene that control its oxygen-dependent transcription. ${ }^{39-41,43,70}$ An $8 \mathrm{~kb}$ kidney-inducibility element is located in the 5'-region of the $E P O$ gene and is required for renal $E P O$ transcription. A liver-inducibility element is situated in the 3'-region of the $E P O$ gene and contains a classic hypoxia enhancer, which is required for the hypoxic induction of $E P O$ in hepatocytes as demonstrated by genetic studies in mice ${ }^{71-74}$ (Figure 2). Although a putative and highly conserved 5'-hypoxia-response element (HRE) has been identified within the kidney-inducibility region, its role in vivo is unclear. ${ }^{75}$

Hypoxic signalling and iron metabolism-When erythropoiesis is stimulated by hypoxia via a HIF-2-induced increase in plasma erythropoietin level, the HIF-PHD oxygensensing pathway optimizes iron uptake and utilization to meet increased iron demand for erythropoiesis in the bone marrow. HIF-2 has a critical role in the regulation of iron uptake, as it increases transcription of the genes that encode divalent metal transporter 1 (Dmt I) and 
duodenal cytochrome $b$ reductase $1(D c y t b)$ in animal models of iron-deficiency and haemochromatosis ${ }^{54,76,77}$ (Figure 3). DMT1 transports iron into the cytoplasm of cells, and DCYTB reduces ferric iron to its ferrous form $\left(\mathrm{Fe}^{2+}\right)$ before it is taken up from the gut lumen into intestinal cells via DMT1. Other HIF-regulated factors involved in iron regulation include transferrin, which transports iron in its ferric form $\left(\mathrm{Fe}^{3+}\right)$ in plasma, the transferrin receptor (encoded by TFRI) ${ }^{78-80}$ ceruloplasmin, which oxidizes $\mathrm{Fe}^{2+}$ to $\mathrm{Fe}^{3+}$ and is important for iron transport, ${ }^{81}$ haeme-oxygenase-1, which is critical for the recycling of iron from phagocytosed erythrocytes, ${ }^{82}$ and ferroportin (encoded by FPN), ${ }^{83}$ the only known cellular iron exporter, which is targeted for degradation by hepcidin. The small 25 amino acid peptide hepcidin is mainly produced in hepatocytes and suppresses intestinal iron uptake and release of iron from internal stores. ${ }^{84}$ As discussed in further detail below, hepcidin has an important role in the pathogenesis of anaemia of inflammation and in the development of iron-deficiency in patients with chronic kidney disease (CKD). Activation of the HIF pathway by hypoxia, genetic mutations or pharmacologic means suppresses hepcidin production in the liver and thereby enhances iron uptake and mobilization ${ }^{85,86}$ (Figure 3).

As hepatic levels of Hamp1 mRNA — the gene encoding murine hepcidin-were not completely suppressed in iron-deficient hepatocyte-specific HIF-1a knockout mice ( $90 \%$ reduction in Hampl levels compared to control) and chromatin immunoprecipitation studies indicated HIF-1 binding to the Hampl promoter, Peyssonnaux and colleagues suggested that hepcidin is a direct transcriptional target of HIF-1 ${ }^{87}$ However, subsequent studies in mouse models of global and liver-specific HIF activation found that HIF-induced suppression of hep cidin was completely dependent on erythropoietin-mediated stimulation of erythropoiesis. ${ }^{88,89}$ These findings provided strong support for the notion that the suppression of hepcidin under conditions of HIF activation in the liver occurs indirectly via HIF-2-dependent induction of erythropoietin production and not through direct HIFdependent transcriptional regulation. This notion is furthermore supported by genome-wide studies in cell lines, which found no enrichment of HIF-binding loci among genes that were downregulated by HIF, suggesting that HIF does not act as a transcriptional repressor and instead suppresses gene expression indirectly. ${ }^{51}$

Hypoxic signalling in the bone marrow-In addition to regulating iron metabolism, hypoxia and the HIF-PHD pathway have direct effects on the bone marrow. Hypoxia stimulates EPOR expression, regulates components of the haemoglobin synthesis pathway, ${ }^{90-94}$ and modulates stem cell maintenance, lineage differentiation and maturation. ${ }^{95,96}$ Yamashita and colleagues identified a specific role for endothelial HIF-2 in this regard, as mice with globally reduced HIF-2 expression developed defects in erythroid maturation. ${ }^{96}$ This maturation defect seemed to involve vascular adhesion molecule (VCAM)-1, a surface protein that supports erythroid maturation.

\section{Cellular sources of erythropoietin}

Erythropoietin synthesis in the kidney-A 1957 study involving surgical removal of various organs identified the kidney as the main site of physiologic erythropoietin production in adult mammals. ${ }^{97}$ Although several studies in the 1990s suggested that 
erythropoietin was produced in renal epithelial cells, ${ }^{98-101}$ in situ hybridization, immunohistochemistry and findings from various genetic models provide clear evidence that peritubular interstitial fibroblast-like cells are the physiologic source of erythropoietin synthesis in the kidney. ${ }^{73,102-108}$ The term interstitial fibroblast-like cell has been used to indicate that this cell population encompasses a heterogeneous group of non-endothelial renal interstitial cells with molecular and morphologic features that resemble fibroblasts. Studies from our laboratory (V. H. Haase, unpublished work) and from other groups ${ }^{109,110}$ indicate that the majority of peritubular interstitial fibroblast-like cells have the capacity to produce erythropoietin.

Renal erythropoietin-producing cells: The induction of erythropoietin synthesis in the kidney requires stabilization of HIF-2a, which either occurs under hypoxic conditions or when its degradation is inhibited by pharmacologic or genetic means. ${ }^{41,111,112}$ Under normoxic conditions, a small number of renal erythropoietin-producing cells (EPCs) localize to the cortico-medullary region. Under hypoxic conditions the number of EPCs increases proportionally to the degree of hypoxia, resulting in a more wide-spread distribution throughout the entire cortex and outer medulla. ${ }^{103,107,109,110}$ The size of the EPC pool correlates directly with the total level of renal Epo transcription, which in turn correlates directly with the concentration of erythropoietin in blood. ${ }^{107}$ The number of EPCs, therefore, determines renal erythropoietin output and plasma erythropoietin levels (Figure 4a). Pathologic conditions that impede the ability of renal interstitial fibroblast-like cells to synthesize erythropoietin will lead to inadequate erythropoietin production and result in the development of anaemia.

Renal EPCs are unique in their morphologic appearance, as they display dendrite-like processes and express markers that are typically found in neuronal cells, such as microtubule-associated protein 2 (MAP2) and neuro-filament light polypeptide (NFL). ${ }^{107}$ The notion that renal EPCs share similarities to neuronal-type cells is supported by lineage tracing studies in mice with specific genetic manipulations in neural-crest-derived cells. ${ }^{113,114}$ Indeed, erythropoietin expression in a subpopulation of neural crest cells is critical for primitive erythropoiesis in the yolk sac during early embryonic development. ${ }^{114}$ Other cellular surface markers that are typically associated with renal EPCs are ecto-5'nucleotidase (CD73) and platelet-derived growth factor receptor $\beta$ (PDGFRB), the latter being a marker of pericytes, indicating that renal pericytes have the potential to substantially contribute to the EPC pool. ${ }^{105,113}$

Renal interstitial fibroblasts and pericytes are derived from FOXD1-expressing stromal cells (Figure 4b), and morphologic and molecular criteria-for example, physical contact with endothelial cells or the basement membrane and the expression of certain molecular markers, such as desmin, a-smooth muscle actin (a-SMA) or S100 calcium-binding protein A4 (S100A4) - have been used to distinguish these cell types from one another. ${ }^{115}$ Owing to limitations in the specificity of morphologic and molecular features, the accuracy of this classification has been questioned, however. ${ }^{116}$ FOXD1 (also referred to as BF-2) is a forkhead family transcription factor, which, in the developing kidney, is expressed in the nephrogenic interstitium (stroma) that overlies the cap mesenchyme. ${ }^{117}$ In addition to pericytes and interstitial fibroblasts, FOXD1-expressing cells give also rise to vascular 
smooth muscle cells (VSMCs), renin-producing cells, mesangial cells and probably to a subpopulation of renal epithelial cells; Foxdl mRNA has also been detected in podocytes $^{118,119}$ (Figure 4). Genetic studies in mice indicate that renin-producing cells can be stimulated to synthesize erythropoietin under conditions of $V h l$ inactivation. ${ }^{120,121}$ In this context, erythropoietin synthesis resulted from constitutive HIF-2 activation and was associated with a suppression of renin production and changes in the physiologic behaviour of the cells. ${ }^{120,121}$ These findings raise the question of whether erythropoietin production by interstitial fibroblasts and/or pericytes under conditions of prolonged HIF-2 activation is associated with alterations in their normal cellular functions. To address this question, studies that characterize HIF responses in these cell types and the renal microvasculature are needed. Of note, Epo expression has not been observed in VSMCs, mesangial cells, podocytes or renal epithelial cells using in situ hybridization approaches (V. H. Haase, unpublished work).

Transdifferentiation into myofibroblasts: The Foxdl promoter has been used for lineage tracing studies to define the cellular origin of myofibroblasts, which are a main source of collagen production in chronically injured kidneys. These studies suggested that pericytes and not epithelial cells give rise to myofibro-blasts and raised the possibility that pericytes lose their erythropoietin-producing potential during transdifferentiation into myofibroblasts. ${ }^{115,116,122}$ Indeed, genetic fate mapping studies using a $\mathrm{Cre}$-recombinase transgene under the control of the Epo promoter support the concept that transdifferentiation of EPCs into myofibroblasts is the likely mechanism by which EPCs lose their ability to synthesize erythropoietin in the injured kidney ${ }^{109}$ (Figure 5). The inability to produce erythropoietin was associated with an increase in NF- $\kappa \mathrm{B}$ signalling in these cells, and treatment with corticosteroids reversed the loss of erythropoietin-producing ability in animal models of kidney injury. ${ }^{109}$ Whether all renal pericytes have the potential to become EPCs remains to be examined.

Erythropoietin synthesis in the liver-Although the primary physiologic source of erythropoietin synthesis in adults is the kidney, erythropoietin production during embryonic development occurs in the liver. The underlying molecular mechanisms that control the switch from the liver to the kidney as the main physiologic source of erythropoietin are poorly understood. Reduced expression of transcriptional activator GATA4 has been suggested to have a key role during this process. ${ }^{123}$ Although the liver does not contribute to the plasma erythropoietin pool under physiologic conditions in adults, perivenous hepatocytes can be stimulated to synthesize erythropoietin by moderate or severe hypoxia, ${ }^{107}$ which accounts for most of the physiologically relevant systemic erythropoietin of extra-renal origin. ${ }^{124,125}$ Erythropoietin has also been detected in hepatic stellate cells (also referred to as ITO cells). ${ }^{126,127}$ Although induction of erythropoietin by the liver under hypoxic conditions does not correct anaemia in patients with CKD, hepatic HIF can be sufficiently stimulated by pharmacologic means to normalize haematologic parameters in rodent models of anaemia associated with renal failure or inflammation. ${ }^{41,128}$ Robust pharmacologic induction of erythropoietin synthesis in hepatocytes requires inactivation of all three HIF-PHDs or inactivation of the VHL-E3 ubiquitin ligase complex. ${ }^{41,43,129}$ In this regard, hepatocytes behave differently from renal EPCs, which are sensitive to PHD2 
inactivation alone, indicating that HIF degradation in EPCs is regulated in a tissuedependent manner.

Erythropoietin synthesis in other tissues-In addition to the kidney and liver as the two major sources of erythropoietin synthesis, erythropoietin mRNA has been detected in neurons and glial cells, lung tissue, cardiomyocytes, bone marrow cells, spleen, hair follicles, tissues of the male and female genitourinary tract and osteoblasts. ${ }^{130-142}$ Although these cell types are not thought to contribute substantially to plasma erythropoietin levels under physiologic conditions, they might have a role in stress-induced erythropoiesis. ${ }^{142,143}$ Furthermore, local non-renal erythropoietin might exert non-haematopoietic actions on angiogenic and cellular stress responses. ${ }^{144}$ Nevertheless, many of the non-renal cell types have the potential to contribute to erythropoiesis under conditions of systemic HIF activation, which will be an important consideration when administering HIF stabilizing compounds systemically to patients with anaemia. . $^{41,141-143,145}$

Other cellular regulators-Non-EPC-derived signals and messengers, which include uraemic toxins, have the potential to modulate the HIF-erythropoietin axis (see discussion below). ${ }^{146,147}$ For example, production of nitric oxide in macrophages has been identified as a positive regulator of renal erythropoietin production. ${ }^{148} \mathrm{HIF}-1$-mediated and nitric-oxidemediated effects on dermal blood flow might also modulate erythropoietin production indirectly through alterations in renal and hepatic blood flow. ${ }^{149}$ However, this proposal has been challenged, as partial pressure of oxygen $\left(\mathrm{pO}_{2}\right)$ in renal tissue is largely independent of blood flow and is maintained at relatively constant levels under most physiologic conditions. Oxygen consumption in the kidney is physiologically linked to renal blood flow, which determines glomerular filtration rate and thus renal work load so that a potential increase in $\mathrm{pO}_{2}$ from increased blood flow would be offset by an increase in oxygen consumption. ${ }^{150,151}$ Nevertheless, the concept that hypoxia responses in non-renal tissues provide signals that regulate renal erythropoietin production is supported by additional studies. For example, isolated brain hypoxia triggers erythropoietin production in the kidney, probably due to the production of brain stem-derived humoral factors that modulate renal erythropoietin output. ${ }^{152}$

Within the kidney, cross talk between cells with EPC potential and other cells types is likely to affect the regulation of the EPC pool. Although these intercellular relationships are ill defined, studies from our group have shown that HIF-induced reprogramming of epithelial metabolism changes the size of the EPC pool partly through alterations in renal tissue $\mathrm{pO}_{2}$ (V.H. Haase, unpublished work). These findings would be consistent with the observation that certain diuretics can modulate renal erythropoiesis, possibly through their effects on tubular work load and oxygen consumption. ${ }^{153}$

\section{Pathogenesis of renal anaemia}

As mentioned earlier, renal anaemia is caused by under-production of erythrocytes due to multiple factors, among which erythropoietin deficiency is most prominent and specific (Figure 6). Most patients with a glomerular filtration rate $<30 \mathrm{ml} / \mathrm{min} / 1.73 \mathrm{~m}^{2}$ develop anaemia. ${ }^{154}$ Patients with renal failure have much lower levels of erythropoietin than do 
patients with similar degrees of anaemia but with intact kidney function. ${ }^{155}$ However, among patients with renal failure, nephric patients have higher plasma erythropoietin and haematocrit levels than do anephric patients, indicating that the diseased kidneys achieve residual erythropoietin production. ${ }^{155}$

Erythropoietin deficiency associated with renal disease increases apoptosis of erythroid progenitors in the erythropoietin-dependence period (Figure 1), which leads to decreased reticulocyte production. rhEPO and other erythropoiesis-stimulating agents (ESAs), such as darbepoetin alfa and epoetin beta pegol permit exogenous erythropoietin therapy with major improvements in renal anaemia. Some patients, however, have suboptimal responses or require very high ESA doses to respond. These erythropoietin-resistant patients most commonly have considerable inflammation and/or iron deficiency, which suppresses erythropoietin production and has negative effects on erythropoietic progenitor cells.

The role of inflammation-Systemic inflammation in renal failure is often caused by autoimmune diseases and infections related to diabetes mellitus and/or use of intravascular devices. Bone marrow inflammatory cytokines are increased in patients with renal osteodystrophy ${ }^{156,157}$ — a condition that is associated with erythropoietin resistance. A link between inflammation and decreased erythropoiesis was demonstrated by relatively decreased levels of serum erythropoietin in anaemic patients without renal failure who had inflammation caused by autoimmune disease ${ }^{158}$ or malignancies ${ }^{159}$ as opposed to levels in similarly anaemic patients without inflammation. In a rat model of inflammation, IL-1 $\beta$ acted indirectly through TNF, to suppress renal erythropoietin production. ${ }^{160}$ Inflammation accompanying the acute exacerbation of chronic renal insufficiency in murine models transformed renal erythropoietin-producing fibroblast-like cells into proliferating myofibroblasts, with TNF signalling through NF- $\mathrm{KB}$ suppressing Epo transcription ${ }^{109}$ (Figure 5).

In addition to their suppressive effects on erythropoietin production, several inflammatory cytokines, including IL-6, TNF and interferon- $\gamma$ (IFN- $\gamma),{ }^{161}$ inhibit differentiation of erythropoietic progenitors. IFN- $\gamma$ induces PU.1, suppressing erythroid differentiation and promoting granulocytic-monocytic differentiation. ${ }^{162}$ During the erythropoietin-dependence stages (Figure 1), IFN- $\gamma$ enhances expression of apoptosis-inducing TNF receptor family members including receptors for TNF, FAS, TRAIL, TWEAK and RCAS1. ${ }^{163-165}$ In later stages of erythropoiesis when iron is required for haemoglobin production (Figure 1), inflammation and/ or infection restricts iron supply to the bone marrow by inducing transcription of HAMP (which encodes hepcidin) via IL-6 signalling through the STAT3 pathway ${ }^{166}$ and activin B signalling through the BMP/Smad1/5/8 pathway. ${ }^{167}$ Hepcidin binds to the iron exporter ferroportin, leading to its internalization and degradation and thereby downregulates ferroportin expression on all cells. ${ }^{168}$ The key cells that supply iron to erythroid cells for haemoglobin synthesis and are affected by hepcidin are macrophages, which recycle iron from phagocytosed senescent erythrocytes; hepatocytes, which are the major storage cells for iron; and duodenal enterocytes, which absorb dietary iron (Figure 3).

The effects of iron deficiency-Although inflammation restricts iron availability for haemoglobin synthesis, absolute iron deficiency occurs in CKD-associated anaemia because 
haemodialysis causes recurrent blood loss. Erythrocytes, which contain two-thirds of the body's iron, are lost by trapping in dialysis apparatuses and associated tubing, post-dialysis bleeding at vascular access sites, and recurrent sampling for laboratory tests. These blood losses are four to eight-fold higher than the normal daily loss of 1-2 mg of iron that occurs via the gastrointestinal tract and skin under physiological conditions, ${ }^{169-172}$ and lead to iron deficiency because oral iron absorption, even if supplemented, is insufficient to replace the losses. ${ }^{173,174}$ Under normal conditions, haemoglobin-synthesizing erythroid cells are the largest consumers of iron (consuming about $25 \mathrm{mg}$ per day), and macrophages, which phagocytose senescent erythrocytes and recycle iron from degraded haemoglobin, are the largest suppliers. After bleeding or haemolysis, mobilization of stored and recycled iron and absorption of duodenal iron are increased by erythroferrone, a hormone produced by erythropoietin-stimulated erythroblasts that decreases production of hepcidin. ${ }^{175} \mathrm{In}$ renal disease, erythropoietin deficiency and chronic inflammation result in reduced numbers of erythroblasts that are the source of erythroferrone (Figure 6).

As iron deficiency progresses, erythropoietic utilization of iron becomes limited while crucial iron-requiring processes in non-erythroid cells are preserved. Iron regulatory proteins (IRP1 and IRP2) bind to iron responsive elements (IREs) in 5'-untranslated regions (UTRs) and 3' UTRs of mRNAs that control expression of proteins involved in cellular iron import, export and storage. ${ }^{176,177}$ In iron-replete cells, IRP1 has aconitase activity with an ironsulphur cluster in its active site, and IRP2 is rapidly degraded. In iron-deficient cells, IRP1 and IRP2 bind IREs, as IRP1 lacks its iron-sulphur cluster and IRP2 is stabilized. IRPs bound to 5'-UTR IREs of mRNAs inhibit translation and expression, while IREs bound to 3'-UTRs of mRNAs stabilizes them, increasing translation and expression. In most cells, ferroportin mRNA is regulated by a 5'-IRE, and the resultant decrease in iron export conserves intracellular iron levels. Alternative splicing in duodenal enterocytes and erythroid precursor cells, however, produces ferroportin mRNAs without 5'-IREs, ${ }^{178,179}$ and persistent ferroportin expression during iron deficiency enables iron absorption from the duodenum and diminishes iron accumulation within erythroid precursors. ${ }^{180}$

Under conditions of iron deficiency, IRPs exhibit increased binding to 5'-IREs of two other mRNAs involved in erythropoiesis: HIF-2 $a$ and ALAS2. Binding of IRP1 to a 5'-IRE in HIF-2a mRNA inhibits HIF-2a translation in renal cortical EPCs, ${ }^{181-183}$ with relatively decreased levels of HIF-2a protein restricting erythropoietin production despite the presence of hypoxia in the renal cortex caused by decreased numbers of circulating erythrocytes. Although erythropoietin production is significantly greater in iron-deficiency anaemia than in anaemia associated with renal failure or chronic inflammation (such as that associated with malignancies, infections or autoimmune disorders), IRP-mediated restriction of HIF-2a translation is predicted to reduce renal erythropoietin synthesis in iron-deficiency anaemia relative to non-iron deficient, acquired anaemia of similar severity, such as haemolytic or megaloblastic anaemia. Iron deficiency also leads to binding of IRP to a 5'-IRE in mRNA encoding ALAS2, the rate-controlling enzyme in porphyrin synthesis, ${ }^{9}$ which decreases accumulation of protoporphyrin and haeme in erythroblasts. Decreased haeme, in turn, increases HRI activity, which inhibits erythroblast protein synthesis. ${ }^{10}$ Iron deficiency therefore results in less than maximal erythropoietin production, which reduces the number of erythroid progenitors surviving the erythropoietin-dependence period and HRI inhibits 
erythroblast protein synthesis in the haemoglobin synth esis period, resulting in the production of fewer and smaller erythrocytes containing smaller amounts of haemoglobin.

\section{Stabilizing HIF to treat renal anaemia}

ESAs and intravenous iron supplementation represent the current mainstay of renal anaemia therapy. Although very effective in most patients, ESA therapy and variability in haemoglobin level due to ESA use has been associated with increased cardiovascular risk. ${ }^{184-189}$ Pharmacologic activation of HIF responses offers great therapeutic potential, and is predicted to provide a more physiologic approach to treating renal anaemia than current approaches, thus potentially reducing the cardiovascular risks associated with recombinant erythropoietin therapy. Major benefits of anaemia therapy with HIF stabilizers include maintenance of plasma erythropoietin levels within a physiologic range, which would avoid the supraphysiologic increases in plasma erythropoietin levels that are often associated with intravenous ESA therapy; enhanced iron absorption and mobilization, which could lead to a reduction in the use of intravenous iron supplementation; and oral dosing with the potential for more effective titrability, which would reduce the fluctuations in haematological parameters and minimize the risk of over-reaching haematologic targets.

Development of HIF stabilizers-Although it had been known since the 1980s that $E P O$ transcription and HIF responses could be activated with iron chelators and transition metals such as cobalt and nickel, ${ }^{190-194}$ the discovery of PHDs as oxygen sensors provided a structural basis for the development of HIF activating compounds, called PHD inhibitors (PHIs). Before the discovery of the HIF pathway, cobalt, despite its potential for serious adverse effects, had been used clinically for the treatment of anaemia in patients on haemodialysis. ${ }^{195-198}$ Cobalt acts as a nonspecific hypoxia mimic by inhibiting HIF-PHDs and other 2OG-dependent oxygenases, but its effects on gene expression overlap only partially with those induced by hypoxia ( $28 \%$ overlap in gene expression profiles obtained from hypoxia-treated and cobalt(II)-chloride-treated hepatoma cells). ${ }^{199,200}$ Although no longer in clinical use, the pathologic effects of cobalt are still relevant to clinical practice, as cobalt poisoning of food and drinking water represents a serious health problem in Andean high altitude populations, and should be considered as a potential cause in cases of unexplained polycythaemia. ${ }^{201}$

The majority of PHIs developed through structure-based drug discovery programmes reversibly inhibit PHD catalytic activity by binding to the ferrous-iron-containing active site, thereby blocking entry of the cosubstrate $2 \mathrm{OG} .{ }^{202}$ Since PHDs belong to a large family of 2OG-dependent oxygenases, PHD-inhibiting compounds can theoretically affect the function of other 2OG-dependent oxygenases, such as tet proteins, jumonji domaincontaining oxygenases and others, which target non-HIF substrates. ${ }^{63,203}$ These potential off-target effects will require careful consideration in the preclinical and clinical evaluation of HIF-activating PHIs. To date, six PHIs, which aim to stimulate endogenous erythropoietin synthesis and other cellular HIF responses, are registered in clinical trials (Table 1). Data from these trials, presented in abstract form at clinical society meetings or on company websites, ${ }^{204-206}$ indicate that pharmacological inhibition of HIF-PHDs is well tolerated by patients, is effective in raising and maintaining haemoglobin in patients with 
CKD and end-stage renal disease (ESRD) who were ESA-naive or converted from an ESA to a PHI, and has the predicted beneficial effects on iron metabolism.

In a proof-of-principle study, a single dose of the PHI FG-2216 significantly increased serum erythropoietin levels in patients on haemodialysis. Suprisingly, the erythropoietin response was more pronounced in nephric patients on haemodialysis than in healthy individuals, whereas anephric patients on haemodialysis responded with lower serum erythropoietin levels compared to healthy controls or nephric patients with ESRD. ${ }^{207}$ This enhanced serum erythropoietin response in nephric patients on haemodialysis might have resulted from changes in compound metabolism and pharmacokinetics due to impaired renal clearance, but also raises the possibility that ESRD kidneys might be more susceptible to the erythropoietin-stimulating effects of PHD inhibition. Although the underlying mechanisms behind such increased susceptibility are likely to be complex, they may involve the presence of renal hypoxia, which as described earlier, is a well-documented pathophysio-logic feature of CKD that is predicted to affect PHD catalytic activity, thus possibly enhancing the effects of pharmacologic PHD inhibition. ${ }^{208,209}$

In order to understand and predict the physiologic and clinical effects of PHIs in patients with CKD and anaemia, it is important to consider the degree to which individual PHDs are selectively targeted, and whether a certain compound might result in tissue-specific stimulation of erythropoietin production (that is, in the kidney versus the liver). Tissuespecific effects might result from differences in the tissue distribution of the compounds or reflect differences in PHD selectivity. Genetic studies in mice have shown that inactivation of PHD2 alone is sufficient to boost renal erythropoietin production, ${ }^{111,112}$ whereas the combined inactivation of PHD1, PHD2 and PHD3 is required to induce robust and sustained erythropoietin synthesis in hepatocytes. ${ }^{129}$ In terms of efficacy, the kidney contains a large subset of peritubular renal interstitial fibroblast-like cells that are sensitive to PHD2 inactivation alone, whereas inhibition of additional PHDs is required for the stabilization of HIF-2a and induction of erythropoietin in other subsets of peritubular interstitial fibroblastlike cells (V.H. Haase, unpublished work). These findings indicate that cell types with erythropoietin-producing capability display differential sensitivity to PHD inhibition, which will be an important c onsideration in the clinical evaluation of PHI therapy.

Potential disadvantages of PHI therapy-Although PHI therapy represents a promising novel approach for the treatment of renal anaemia and has several potential advantages over conventional ESA therapy, theoretical downsides need to be addressed in clinical trials. HIF-specific PHIs are administered systemically and target the oxygensensing machinery upstream of HIF, which will lead to various degrees of HIF-1 and HIF-2 activation depending on which PHDs, tissues and cell types are targeted. Since HIF transcription factors are involved in the regulation of a broad spectrum of biological processes, careful clinical safety and cardiovascular outcome studies will need to be conducted in patients with CKD to evaluate PHI-mediated effects on renal disease progression, metabolism, cardiovascular function, blood pressure, and other physiologic parameters. ${ }^{210} \mathrm{HIF}$ is involved in the regulation of vascular tone and blood pressure and has been shown to contribute to the development of pulmonary hypertension. ${ }^{210-213}$ Furthermore, activation of HIF signalling in malignant cells has been associated with the 
initiation and progression of various tumours, as well as resistance to therapy involving multiple levels of regulation, which precludes the use of HIF-stimulating compounds in patients with cancer. ${ }^{214-216}$ Of considerable concern are the possible effects of global HIF activation on angiogenesis, particularly as it relates to the progression of proliferative diabetic retinopathy and tumour angiogenesis. Vascular endothelial growth factor (VEGF) is a HIF-regulated growth factor and systemic activation of the HIF axis has the potential to lead to increased VEGF production in multiple tissues. ${ }^{217}$ Clinical studies will need to carefully screen for potential pro-angiogenic effects and other PHI-induced hypoxia responses that might be harmful to patients.

The clinical complexity of patients with advanced CKD, their often complex medication regimen and the possibility of broad-spectrum on-target biological effects might make it difficult to define causal relationships when severe adverse clinical events occur. Accordingly, the FDA temporarily suspended a phase II clinical trial with the HIF stabilizer FG-2216 due to a single case of fatal hepatic necrosis. Although the FDA granted permission to resume clinical trials with FG-2216 in 2008,218 no further studies using this agent have been performed in humans.

\section{HIF activators in clinical trials}

Many HIF stabilizers originated from drug development programmes that initially developed the compounds to inhibit collagen hydroxylases for anti-fibrotic therapy. Noxalylglycine (NOG) and dimethyl-oxalylglycine (DMOG) are examples of compounds that were developed under these programmes and have been widely used in preclinical investigations to study the effects of pharmacologic HIF activation on mammalian physiology and disease. Consequently, hydroxyisoquinoline-based compounds were developed that contain a carbonylglycine side chain. ${ }^{219}$ Examples of this class of PHIs are the FibroGen compounds FG-2216 and FG-4592. The latter compound differs from FG-2216 by the addition of a phenoxy substituent at carbon position seven of the quinoline core (Supplementary Figure 1). ${ }^{219,220}$

FG-4592-FG-4592 is FibroGen's current lead anaemia compound with clinical data from over 1,000 patients presented at international scientific and clinical meetings. ${ }^{221-224}$ FG-4592 inhibits all three HIF-PHDs, has a plasma half-life of $\sim 12 \mathrm{~h}$ and has mostly been given orally in bi-weekly or tri-weekly doses ranging from $1 \mathrm{mg} / \mathrm{kg}$ to $2 \mathrm{mg} / \mathrm{kg}$. Similar to FG-2216, FG-4592 stimulates the transcription of endogenous EPO and other genes involved in erythropoiesis, such as EPOR and genes that regulate iron absorption, transport and recycling. ${ }^{221,225}$ Clinical studies in patients with CKD not on dialysis, as well as in those on haemodialysis or peritoneal dialysis, including erythropoietin-naive patients, demonstrate that FG-4592 is well tolerated, maintains haemoglobin levels within the target range and has beneficial effects on iron metabolism. ${ }^{222}$ FG-4592 increases total iron binding capacity independent of route of administration, decreases serum ferritin levels and consistently lowers hepcidin levels. ${ }^{222}$ Furthermore, the effectiveness of FG-4592 on erythropoiesis does not seem to be affected by inflammation, as total dose requirements to maintain haemoglobin levels in the target range were not associated with C-reactive protein levels. ${ }^{222}$ Median peak serum erythropoietin levels $8-12 \mathrm{~h}$ after administration of $1 \mathrm{mg} / \mathrm{kg}$ 
FG-4592 were $115 \mathrm{mU} / \mathrm{ml},{ }^{223}$ substantially lower than those achieved by intravenous injection of rhEPO. ${ }^{226} \mathrm{~A}$ phase II comparison study of patients on haemodialysis treated with FG-4592 or epoetin alfa also indicated suppressive effects of FG-4592 on lipid metabolism, with a significant $20 \%$ reduction in total serum cholesterol observed in FG-4592-treated patients compared to those treated with recombinant epoetin alfa. ${ }^{224}$ Whether this finding represents a HIF-mediated and/or drug class effect remains to be investigated. Studies with FG-4592 have now entered phase III clinical trials (Table 1).

GSK1278863-GlaxoSmithKline's compound GSK1278863 is being tested in phase II clinical trials for renal anaemia (Table 1) and is also being investigated for potential benefits in ischaemia prevention and wound healing. Although the structure of GSK1278863 has not been published, it is probably similar to a commercially available test compound, GSK1002083A, which is a robust HIF-1 and HIF-2 activator and has been used for various preclinical proof-of-principle studies in mice. ${ }^{41,227}$ GSK1278863 inhibits PHD2 and PHD3 with an $\mathrm{IC}_{50}$ of $22 \mathrm{nM}$ and $5.5 \mathrm{nM}$, respectively, and leads to the stabilization of both HIF-1a and HIF-2a in Hep3B cells. ${ }^{228}$ In mice, oral administration of $60 \mathrm{mg} / \mathrm{kg}$ GSK1278863 led to rapid induction of liver Epo mRNA followed by the induction of kidney Epo message after $6 \mathrm{~h}$, which corresponded to an eightfold increase in serum erythropoietin levels from baseline 6-8 $\mathrm{h}$ after drug administration. ${ }^{228}$ Daily oral gavage for 21 days was associated with increases in all erythrocyte parameters. ${ }^{228}$ In a safety and tolerability study in healthy individuals, oral administration of single doses of 2-300 mg led to dosedependent increases in serum erythropoietin levels (up to 1,000-fold in the $300 \mathrm{mg}$ group). Doses of $150 \mathrm{mg}$ and $300 \mathrm{mg}$ were also associated with significant increases in serum VEGF levels compared to placebo control. ${ }^{229}$ In a separate study, administration of $10-100 \mathrm{mg}$ GSK1278863 to patients with non-dialysis stage 3-5 CKD and haemodialysis-dependent CKD led to dose-dependent changes in haema tologic parameters and decreased serum hep cidin levels, ${ }^{230}$ with no significant change in serum VEGF levels at the investigated doseranges. GSK1278863 is also being evaluated in the context of wound healing and ischaemic injury associated with thoracic aortic aneur ysm repair. A multicentre, randomized, placebocontrolled phase II clinical study in patients with peripheral artery disease and symptomatic claudication has been completed but did not show benefits with regard to exercise performance at the doses studied. ${ }^{231}$

AKB-6548-Akebia Therapeutics has completed phase IIa and phase IIb trials of its lead anaemia therapy compound, AKB-6548, in patients with nondialysis-dependent CKD, and is currently enrolling patients on haemo-dialysis (Table 1). The structure of AKB-6548 is not published; however, it is probably based on a series of 8-hydroxyquinoline 7-carboxamide compounds. ${ }^{219}$ AKB-6548 stabilizes HIF2a to a greater extent than HIF1a and produces dose-dependent increases in serum erythropoietin levels. Serum erythropoietin peaked $\sim 18 \mathrm{~h}$ after administration of AKB-6548 and reached $32.4 \mathrm{mU} / \mathrm{ml}$ in healthy adults when daily doses of $900 \mathrm{mg}$ were given in a 10-day phase Ib study. ${ }^{232}$ Comparable increases were seen in patients with stage 3 and 4 CKD, who were given a single $500 \mathrm{mg}$ dose. AKB-6548 seems to be well tolerated in patients with CKD, raises and maintains haemoglobin levels in the target range, increases total iron binding capacity and lowers both serum ferritin and hepcidin levels. ${ }^{233-235}$ A slight transient decrease in mean arterial blood pressure and a mild 
transient increase in serum uric acid level were observed in a 28-day dose escalation study. ${ }^{233}$ An increase in serum uric acid levels is a typical finding in individuals who ascend to high altitude, supporting the notion that PHIs mimic various aspects of high altitude physiology. ${ }^{236,237}$ In a randomized, double blind, placebo-controlled phase II study, daily doses of $240 \mathrm{mg}, 370 \mathrm{mg}, 500 \mathrm{mg}$ and $630 \mathrm{mg}$ AKB-6548 were given to patients with stage 3 and 4 CKD over a period of 6 weeks. Statistically significant increases in haemoglobin values, ranging from $\sim 7.5 \mathrm{~g} / \mathrm{l}$ to $15 \mathrm{~g} / \mathrm{l}$, were observed in all dosing groups, whereas serum erythropoietin levels were not statistically significantly different between patients who received AKB-6548 and those who received placebo, ${ }^{234}$ indicating that PHI therapy is effective in treating renal anaemia within physiologic ranges of plasma erythropoietin.

BAY85-3934-Bayer compound BAY85-3934 (Molidustat) is structurally different from the aforementioned compounds in that it is based on a dihydropyrazolone ring structure that does not contain a carbonylglycine side chain. This compound inhibits all 3 HIF-PHDs with a moderate preference for PHD2 ( $\mathrm{IC}_{50}$ of $480 \mathrm{nM}, 280 \mathrm{nM}$ and $450 \mathrm{nM}$ for PHD1, PHD2 and PHD3, respectively) ${ }^{238}$ and is currently in phase II clinical trials (Table 1).

BAY85-3934 effectively stimulates erythropoiesis in animal models of renal failure and inflammatory anaemia and in addition, demonstrated antihypertensive and cardioprotective effects in partially nephrectomized rats. ${ }^{238}$ In humans, administration of 5-50 mg BAY85-3934 led to a dose-dependent increase in serum erythropoietin levels. ${ }^{239} \mathrm{~A}$ peak serum erythropoietin level of $39.8 \mathrm{mU} / \mathrm{ml}$ was observed $12 \mathrm{~h}$ after a single dose of $50 \mathrm{mg}$ in healthy humans (compared with $14.8 \mathrm{mU} / \mathrm{ml}$ for placebo). ${ }^{239}$

Other HIF stabilizing compounds-Little information is available about two other compounds that are registered for phase I anaemia trials. Akros Pharma is investigating a glycinamide-based compound, JTZ-951, and Daiichi Sankyo has launched phase I clinical trials investigating DS-1093 (Table 1). Preclinical or clinical data are currently not publically available for either compound.

\section{Conclusions}

Improved insights into the oxygen-dependent regulation of erythropoiesis and the relationships between erythropoietin, iron and chronic inflammation provide fascinating opportunities for the development of novel therapeutics that could deliver physiologic and more comprehensive approaches to erythropoietin and iron deficiencies in renal anaemia. These discoveries have led to the development of various HIF stabilizing compounds that are currently being investigated in clinical trials. Although initial findings suggest that the strategy of HIF stabilization to stimulate erythropoiesis in patients with kidney disease is clinically effective, several safety concerns exist. These include the possibility of proangiogenic and adverse cardiovascular and metabolic effects, which need to be carefully assessed in long-term clinical trials. While some of these studies are planned or currently ongoing, knowledge of the effects of systemic HIF activation on human physiology and pathophysiology is still limited and remains an active area of research. 


\section{Supplementary Material}

Refer to Web version on PubMed Central for supplementary material.

\section{Acknowledgements}

V.H.H. is affiliated with the Medicine and Research Services, Department of Veterans Affairs Hospital, Tennessee Valley Healthcare System, Nashville, TN, USA and is supported by the Krick-Brooks Chair in Nephrology, by NIH grants (R01-DK081646, R01-DK080821 and R01-DK101791), and by a Department of Veterans Affairs Merit Award (1I01BX002348).

\section{References}

1. Mancini E, et al. FOG-1 and GATA-1 act sequentially to specify definitive megakaryocytic and erythroid progenitors. EMBO J. 2012; 31:351-365. [PubMed: 22068055]

2. Siatecka M, Bieker JJ. The multifunctional role of EKLF/KLF1 during erythropoiesis. Blood. 2011; 118:2044-2054. [PubMed: 21613252]

3. Gregory CJ, Eaves AC. Human marrow cells capable of erythropoietic differentiation in vitro: definition of three erythroid colony responses. Blood. 1977; 49:855-864. [PubMed: 861374]

4. Chasis JA, Mohandas N. Erythroblastic islands: niches for erythropoiesis. Blood. 2008; 112:470478. [PubMed: 18650462]

5. Nagata S. Autoimmune diseases caused by defects in clearing dead cells and nuclei expelled from erythroid precursors. Immunol. Rev. 2007; 220:237-250. [PubMed: 17979851]

6. Ney PA. Normal and disordered reticulocyte maturation. Curr. Opin. Hematol. 2011; 18:152-157. [PubMed: 21423015]

7. Willekens FL, et al. Erythrocyte vesiculation: a self-protective mechanism? Br. J. Haematol. 2008; 141:549-556. [PubMed: 18419623]

8. Koury MJ. Abnormal erythropoiesis and the pathophysiology of chronic anemia. Blood Rev. 2014; 28:49-66. [PubMed: 24560123]

9. Ponka P. Tissue-specific regulation of iron metabolism and heme synthesis: distinct control mechanisms in erythroid cells. Blood. 1997; 89:1-25. [PubMed: 8978272]

10. Chen JJ. Regulation of protein synthesis by the heme-regulated eIF2a kinase: relevance to anemias. Blood. 2007; 109:2693-2699. [PubMed: 17110456]

11. Sun J, et al. Heme regulates the dynamic exchange of Bach1 and NF-E2-related factors in the Maf transcription factor network. Proc. Natl Acad. Sci. USA. 2004; 101:1461-1466. [PubMed: 14747657]

12. Zenke-Kawasaki $Y$, et al. Heme induces ubiquitination and degradation of the transcription factor Bach1. Mol. Cell Biol. 2007; 27:6962-6971. [PubMed: 17682061]

13. Koury MJ, Sawyer ST, Brandt SJ. New insights into erythropoiesis. Curr. Opin. Hematol. 2002; 9:93-100. [PubMed: 11844990]

14. Panzenbock B, Bartunek P, Mapara MY, Zenke M. Growth and differentiation of human stem cell factor/erythropoietin-dependent erythroid progenitor cells in vitro. Blood. 1998; 92:3658-3668. [PubMed: 9808559]

15. Bauer A, et al. The glucocorticoid receptor is required for stress erythropoiesis. Genes Dev. 1999; 13:2996-3002. [PubMed: 10580006]

16. Zhang L, et al. ZFP36L2 is required for self-renewal of early burst-forming unit erythroid progenitors. Nature. 2013; 499:92-96. [PubMed: 23748442]

17. Paulson RF, Shi L, Wu DC. Stress erythropoiesis: new signals and new stress progenitor cells. Curr. Opin. Hematol. 2011; 18:139-145. [PubMed: 21372709]

18. Millot S, et al. Erythropoietin stimulates spleen BMP4-dependent stress erythropoiesis and partially corrects anemia in a mouse model of generalized inflammation. Blood. 2010; 116:60726081. [PubMed: 20844235] 
19. Livnah O, et al. Crystallographic evidence for preformed dimers of erythropoietin receptor before ligand activation. Science. 1999; 283:987-990. [PubMed: 9974392]

20. Koury MJ. Erythropoietin: the story of hypoxia and a finely regulated hematopoietic hormone. Exp. Hematol. 2005; 33:1263-1270. [PubMed: 16263408]

21. Youssoufian H, Longmore G, Neumann D, Yoshimura A, Lodish HF. Structure, function, and activation of the erythropoietin receptor. Blood. 1993; 81:2223-2236. [PubMed: 8481505]

22. Sawyer ST, Penta K. Erythropoietin cell biology. Hematol. Oncol. Clin. North Am. 1994; 8:895911. [PubMed: 7852213]

23. Gross AW, Lodish HF. Cellular trafficking and degradation of erythropoietin and novel erythropoiesis stimulating protein (NESP). J. Biol. Chem. 2006; 281:2024-2032. [PubMed: 16286456]

24. Witthuhn BA, et al. JAK2 associates with the erythropoietin receptor and is tyrosine phosphorylated and activated following stimulation with erythropoietin. Cell. 1993; 74:227-236. [PubMed: 8343951]

25. Huang LJ, Constantinescu SN, Lodish HF. The N-terminal domain of Janus kinase 2 is required for Golgi processing and cell surface expression of erythropoietin receptor. Mol. Cell. 2001; 8:13271338. [PubMed: 11779507]

26. Richmond TD, Chohan M, Barber DL. Turning cells red: signal transduction mediated by erythropoietin. Trends Cell Biol. 2005; 15:146-155. [PubMed: 15752978]

27. Koury MJ, Bondurant MC. Maintenance by erythropoietin of viability and maturation of murine erythroid precursor cells. J. Cell Physiol. 1988; 137:65-74. [PubMed: 2459142]

28. Koury MJ, Bondurant MC. Erythropoietin retards DNA breakdown and prevents programmed death in erythroid progenitor cells. Science. 1990; 248:378-381. [PubMed: 2326648]

29. Muta K, Krantz SB. Apoptosis of human erythroid colony-forming cells is decreased by stem cell factor and insulin-like growth factor I as well as erythropoietin. J. Cell Physiol. 1993; 156:264271. [PubMed: 7688370]

30. Wu H, Liu X, Jaenisch R, Lodish HF. Generation of committed erythroid BFU-E and CFU-E progenitors does not require erythropoietin or the erythropoietin receptor. Cell. 1995; 83:59-67. [PubMed: 7553874]

31. Kelley LL, et al. Survival or death of individual proerythroblasts results from differing erythropoietin sensitivities: a mechanism for controlled rates of erythrocyte production. Blood. 1993; 82:2340-2352. [PubMed: 8400286]

32. Rubiolo C, et al. A balance between Raf-1 and Fas expression sets the pace of erythroid differentiation. Blood. 2006; 108:152-159. [PubMed: 16527894]

33. De Maria R, et al. Apoptotic role of Fas/Fas ligand system in the regulation of erythropoiesis. Blood. 1999; 93:796-803. [PubMed: 9920828]

34. Liu Y, et al. Suppression of Fas-FasL coexpression by erythropoietin mediates erythroblast expansion during the erythropoietic stress response in vivo. Blood. 2006; 108:123-133. [PubMed: 16527892]

35. Koulnis M, Liu Y, Hallstrom K, Socolovsky M. Negative autoregulation by Fas stabilizes adult erythropoiesis and accelerates its stress response. PLoS ONE. 2011; 6:e21192. [PubMed: 21760888]

36. Eymard N, Bessonov N, Gandrillon O, Koury MJ, Volpert V. The role of spatial organization of cells in erythropoiesis. J. Math. Biol. 2015; 70:71-97. [PubMed: 24496930]

37. Rhodes MM, Kopsombut P, Bondurant MC, Price JO, Koury MJ. Bcl- $x_{L}$ prevents apoptosis of late-stage erythroblasts but does not mediate the antiapoptotic effect of erythropoietin. Blood. 2005; 106:1857-1863. [PubMed: 15899920]

38. Koulnis M, et al. Contrasting dynamic responses in vivo of the Bcl-xL and Bim erythropoietic survival pathways. Blood. 2012; 119:1228-1239. [PubMed: 22086418]

39. Scortegagna M, Morris MA, Oktay Y, Bennett M, Garcia JA. The HIF family member EPAS1/ HIF-2a is required for normal hematopoiesis in mice. Blood. 2003; 102:1634-1640. [PubMed: 12750163]

40. Gruber M, et al. Acute postnatal ablation of Hif-2alpha results in anemia. Proc. Natl Acad. Sci. USA. 2007; 104:2301-2306. [PubMed: 17284606] 
41. Kapitsinou PP, et al. Hepatic HIF-2 regulates erythropoietic responses to hypoxia in renal anemia. Blood. 2010; 116:3039-3048. [PubMed: 20628150]

42. Yoon D, et al. Hypoxia-inducible factor-1 deficiency results in dysregulated erythropoiesis signaling and iron homeostasis in mouse development. J. Biol. Chem. 2006; 281:25703-25711. [PubMed: 16787915]

43. Rankin EB, et al. Hypoxia-inducible factor-2 (HIF-2) regulates hepatic erythropoietin in vivo. J. Clin. Invest. 2007; 117:1068-1077. [PubMed: 17404621]

44. Lee FS, Percy MJ. The HIF pathway and erythrocytosis. Annu. Rev. Pathol. 2011; 6:165-192. [PubMed: 20939709]

45. Simonson TS, McClain DA, Jorde LB, Prchal JT. Genetic determinants of Tibetan high-altitude adaptation. Hum. Genet. 2012; 131:527-533. [PubMed: 22068265]

46. Penaloza D, Arias-Stella J. The heart and pulmonary circulation at high altitudes: healthy highlanders and chronic mountain sickness. Circulation. 2007; 115:1132-1146. [PubMed: 17339571]

47. Kewley RJ, Whitelaw ML, Chapman-Smith A. The mammalian basic helix-loop-helix/PAS family of transcriptional regulators. Int. J. Biochem. Cell Biol. 2004; 36:189-204. [PubMed: 14643885]

48. Semenza GL. Regulation of mammalian $\mathrm{O}_{2}$ homeostasis by hypoxia-inducible factor 1 . Annu. Rev. Cell Dev. Biol. 1999; 15:551-578. [PubMed: 10611972]

49. Wenger RH, Stiehl DP, Camenisch G. Integration of oxygen signaling at the consensus HRE. Sci. STKE. 2005; 2005:re12. [PubMed: 16234508]

50. Semenza GL. HIF-1 and mechanisms of hypoxia sensing. Curr. Opin. Cell Biol. 2001; 13:167171. [PubMed: 11248550]

51. Schodel J, et al. High-resolution genome-wide mapping of HIF-binding sites by ChIP-seq. Blood. 2011; 117:e207-e217. [PubMed: 21447827]

52. Morita M, et al. HLF/HIF-2a is a key factor in retinopathy of prematurity in association with erythropoietin. EMBO J. 2003; 22:1134-1146. [PubMed: 12606578]

53. Scortegagna M, et al. HIF-2a regulates murine hematopoietic development in an erythropoietindependent manner. Blood. 2005; 105:3133-3140. [PubMed: 15626745]

54. Mastrogiannaki M, et al. HIF-2a, but not HIF-1a, promotes iron absorption in mice. J. Clin. Invest. 2009; 119:1159-1166. [PubMed: 19352007]

55. Percy MJ, et al. A gain-of-function mutation in the HIF2A gene in familial erythrocytosis. N. Engl. J. Med. 2008; 358:162-168. [PubMed: 18184961]

56. Jaakkola $\mathrm{P}$, et al. Targeting of HIF-a to the von Hippel-Lindau ubiquitylation complex by $\mathrm{O}_{2-}$ regulated prolyl hydroxylation. Science. 2001; 292:468-472. [PubMed: 11292861]

57. Ivan M, et al. HIFa targeted for VHL-mediated destruction by proline hydroxylation: implications for $\mathrm{O}_{2}$ sensing. Science. 2001; 292:464-468. [PubMed: 11292862]

58. Epstein AC, et al. C. elegans EGL-9 and mammalian homologs define a family of dioxygenases that regulate HIF by prolyl hydroxylation. Cell. 2001; 107:43-54. [PubMed: 11595184]

59. Hon WC, et al. Structural basis for the recognition of hydroxyproline in HIF-1a by pVHL. Nature. 2002; 417:975-978. [PubMed: 12050673]

60. Masson N, Willam C, Maxwell PH, Pugh CW, Ratcliffe PJ. Independent function of two destruction domains in hypoxia-inducible factor-a chains activated by prolyl hydroxylation. EMBO J. 2001; 20:5197-5206. [PubMed: 11566883]

61. Yu F, White SB, Zhao Q, Lee FS. HIF-1a binding to VHL is regulated by stimulus-sensitive proline hydroxylation. Proc. Natl Acad. Sci. USA. 2001; 98:9630-9635. [PubMed: 11504942]

62. Bruick RK, McKnight SL. A conserved family of prolyl-4-hydroxylases that modify HIF. Science. 2001; 294:1337-1340. [PubMed: 11598268]

63. Loenarz C, Schofield CJ. Expanding chemical biology of 2-oxoglutarate oxygenases. Nat. Chem. Biol. 2008; 4:152-156. [PubMed: 18277970]

64. Kaelin WG Jr, Ratcliffe PJ. Oxygen sensing by metazoans: the central role of the HIF hydroxylase pathway. Mol. Cell. 2008; 30:393-402. [PubMed: 18498744] 
65. Percy MJ, et al. A family with erythrocytosis establishes a role for prolyl hydroxylase domain protein 2 in oxygen homeostasis. Proc. Natl Acad. Sci. USA. 2006; 103:654-659. [PubMed: 16407130]

66. Hyvarinen J, et al. Deficiency of a transmembrane prolyl 4-hydroxylase in the zebrafish leads to basement membrane defects and compromised kidney function. J. Biol. Chem. 2010; 285:4202342032. [PubMed: 20952382]

67. Laitala A, et al. Transmembrane prolyl 4-hydroxylase is a fourth prolyl 4-hydroxylase regulating EPO production and erythropoiesis. Blood. 2012; 120:3336-3344. [PubMed: 22955912]

68. Schodel J, et al. HIF-prolyl hydroxylases in the rat kidney: physiologic expression patterns and regulation in acute kidney injury. Am. J. Pathol. 2009; 174:1663-1674. [PubMed: 19349364]

69. Pan X, et al. Isolation and characterization of renal erythropoietin-producing cells from genetically produced anemia mice. PLoS ONE. 2011; 6:e25839. [PubMed: 22022454]

70. Haase VH. Regulation of erythropoiesis by hypoxia-inducible factors. Blood Rev. 2013; 27:41-53. [PubMed: 23291219]

71. Suzuki N, et al. Specific contribution of the erythropoietin gene $3^{\prime}$ enhancer to hepatic erythropoiesis after late embryonic stages. Mol. Cell Biol. 2011; 31:3896-3905. [PubMed: 21746884]

72. Semenza GL, Traystman MD, Gearhart JD, Antonarakis SE. Polycythemia in transgenic mice expressing the human erythropoietin gene. Proc. Natl Acad. Sci. USA. 1989; 86:2301-2305. [PubMed: 2928334]

73. Semenza GL, Koury ST, Nejfelt MK, Gearhart JD, Antonarakis SE. Cell-type-specific and hypoxia-inducible expression of the human erythropoietin gene in transgenic mice. Proc. Natl Acad. Sci. USA. 1991; 88:8725-8729. [PubMed: 1924331]

74. Semenza GL, Dureza RC, Traystman MD, Gearhart JD, Antonarakis SE. Human erythropoietin gene expression in transgenic mice: multiple transcription initiation sites and cis-acting regulatory elements. Mol. Cell Biol. 1990; 10:930-938. [PubMed: 2304468]

75. Storti F, et al. A novel distal upstream hypoxia response element regulating oxygen-dependent erythropoietin gene expression. Haematologica. 2014; 99:e45-e48. [PubMed: 24510339]

76. Shah YM, Matsubara T, Ito S, Yim SH, Gonzalez FJ. Intestinal hypoxia-inducible transcription factors are essential for iron absorption following iron deficiency. Cell. Metab. 2009; 9:152-164. [PubMed: 19147412]

77. Mastrogiannaki M, et al. Deletion of HIF-2a in the enterocytes decreases the severity of tissue iron loading in hepcidin knockout mice. Blood. 2011; 119:587-590. [PubMed: 22128145]

78. Rolfs A, Kvietikova I, Gassmann M, Wenger RH. Oxygen-regulated transferrin expression is mediated by hypoxia-inducible factor-1. J. Biol. Chem. 1997; 272:20055-20062. [PubMed: 9242677]

79. Lok CN, Ponka P. Identification of a hypoxia response element in the transferrin receptor gene. J. Biol. Chem. 1999; 274:24147-24152. [PubMed: 10446188]

80. Tacchini L, Bianchi L, Bernelli-Zazzera A, Cairo G. Transferrin receptor induction by hypoxia. HIF-1-mediated transcriptional activation and cell-specific post-transcriptional regulation. J. Biol. Chem. 1999; 274:24142-24146. [PubMed: 10446187]

81. Mukhopadhyay CK, Mazumder B, Fox PL. Role of hypoxia-inducible factor-1 in transcriptional activation of ceruloplasmin by iron deficiency. J. Biol. Chem. 2000; 275:21048-21054. [PubMed: 10777486]

82. Lee PJ, et al. Hypoxia-inducible factor-1 mediates transcriptional activation of the heme oxygenase-1 gene in response to hypoxia. J. Biol. Chem. 1997; 272:5375-5381. [PubMed: 9038135]

83. Taylor M, et al. Hypoxia-inducible factor- $2 a$ mediates the adaptive increase of intestinal ferroportin during iron deficiency in mice. Gastroenterology. 2011; 140:2044-2055. [PubMed: 21419768]

84. Ganz T. Molecular control of iron transport. J. Am. Soc. Nephrol. 2007; 18:394-400. [PubMed: 17229910]

85. Nicolas G, et al. The gene encoding the iron regulatory peptide hepcidin is regulated by anemia, hypoxia, and inflammation. J. Clin. Invest. 2002; 110:1037-1044. [PubMed: 12370282] 
86. Gordeuk VR, et al. Chuvash polycythemia VHLR200W mutation is associated with downregulation of hepcidin expression. Blood. 2011; 118:5278-5282. [PubMed: 21876117]

87. Peyssonnaux C, et al. Regulation of iron homeostasis by the hypoxia-inducible transcription factors (HIFs). J. Clin. Invest. 2007; 117:1926-1932. [PubMed: 17557118]

88. Mastrogiannaki M, et al. Hepatic hypoxia-inducible factor-2 down-regulates hepcidin expression in mice through an erythropoietin-mediated increase in erythropoiesis. Haematologica. 2012; 97:827-834. [PubMed: 22207682]

89. Liu Q, Davidoff O, Niss K, Haase VH. Hypoxia-inducible factor regulates hepcidin via erythropoietin-induced erythropoiesis. J. Clin. Invest. 2012; 122:4635-4644. [PubMed: 23114598]

90. Chin K, et al. Production and processing of erythropoietin receptor transcripts in brain. Brain Res. Mol. Brain Res. 2000; 81:29-42. [PubMed: 11000476]

91. Manalo DJ, et al. Transcriptional regulation of vascular endothelial cell responses to hypoxia by HIF-1. Blood. 2005; 105:659-669. [PubMed: 15374877]

92. Yoon D, et al. HIF-1a-deficiency results in dysregulated EPO signaling and iron homeostasis in mouse development. J. Biol. Chem. 2006; 281:25703-25711. [PubMed: 16787915]

93. Liu YL, Ang SO, Weigent DA, Prchal JT, Bloomer JR. Regulation of ferrochelatase gene expression by hypoxia. Life Sci. 2004; 75:2035-2043. [PubMed: 15312748]

94. Hofer T, Wenger RH, Kramer MF, Ferreira GC, Gassmann M. Hypoxic up-regulation of erythroid 5-aminolevulinate synthase. Blood. 2003; 101:348-350. [PubMed: 12393745]

95. Adelman DM, Maltepe E, Simon MC. Multilineage embryonic hematopoiesis requires hypoxic ARNT activity. Genes Dev. 1999; 13:2478-2483. [PubMed: 10521392]

96. Yamashita T, et al. The microenvironment for erythropoiesis is regulated by HIF-2a through VCAM-1 in endothelial cells. Blood. 2008; 112:1482-1492. [PubMed: 18451309]

97. Jacobson LO, Goldwasser E, Fried W, Plzak L. Role of the kidney in erythropoiesis. Nature. 1957; 179:633-634. [PubMed: 13418752]

98. Loya F, Yang Y, Lin H, Goldwasser E, Albitar M. Transgenic mice carrying the erythropoietin gene promoter linked to lacZ express the reporter in proximal convoluted tubule cells after hypoxia. Blood. 1994; 84:1831-1836. [PubMed: 8080988]

99. Mujais SK, Beru N, Pullman TN, Goldwasser E. Erythropoietin is produced by tubular cells of the rat kidney. Cell Biochem. Biophys. 1999; 30:153-166. [PubMed: 10099826]

100. Haidar MA, et al. Electron microscopic localization of lacZ expression in the proximal convoluted tubular cells of the kidney in transgenic mice carrying chimeric erythropoietin/lacZ gene constructs. J. Struct. Biol. 1997; 118:220-225. [PubMed: 9169231]

101. Maxwell AP, Lappin TR, Johnston CF, Bridges JM, McGeown MG. Erythropoietin production in kidney tubular cells. Br. J. Haematol. 1990; 74:535-539. [PubMed: 2189493]

102. Lacombe $\mathrm{C}$, et al. Peritubular cells are the site of erythropoietin synthesis in the murine hypoxic kidney. J. Clin. Invest. 1988; 81:620-623. [PubMed: 3339134]

103. Koury ST, Bondurant MC, Koury MJ. Localization of erythropoietin synthesizing cells in murine kidneys by in situ hybridization. Blood. 1988; 71:524-527. [PubMed: 3337914]

104. Koury ST, Koury MJ, Bondurant MC, Caro J, Graber SE. Quantitation of erythropoietinproducing cells in kidneys of mice by in situ hybridization: correlation with hematocrit, renal erythropoietin mRNA, and serum erythropoietin concentration. Blood. 1989; 74:645-651. [PubMed: 2752138]

105. Bachmann S, Le Hir M, Eckardt KU. Co-localization of erythropoietin mRNA and ecto-5'nucleotidase immunoreactivity in peritubular cells of rat renal cortex indicates that fibroblasts produce erythropoietin. J. Histochem. Cytochem. 1993; 41:335-341. [PubMed: 8429197]

106. Maxwell PH, et al. Identification of the renal erythropoietin-producing cells using transgenic mice. Kidney Int. 1993; 44:1149-1162. [PubMed: 8264149]

107. Obara N, et al. Repression via the GATA box is essential for tissue-specific erythropoietin gene expression. Blood. 2008; 111:5223-5232. [PubMed: 18202227]

108. Paliege A, et al. Hypoxia-inducible factor-2a-expressing interstitial fibroblasts are the only renal cells that express erythropoietin under hypoxia-inducible factor stabilization. Kidney Int. 2010; 77:312-318. [PubMed: 20016470] 
109. Souma T, et al. Plasticity of renal erythropoietin-producing cells governs fibrosis. J. Am. Soc. Nephrol. 2013; 24:1599-1616. [PubMed: 23833259]

110. Yamazaki S, et al. A mouse model of adult-onset anaemia due to erythropoietin deficiency. Nat. Commun. 2013; 4:1950. [PubMed: 23727690]

111. Takeda K, et al. Regulation of adult erythropoiesis by prolyl hydroxylase domain proteins. Blood. 2008; 111:3229-3235. [PubMed: 18056838]

112. Minamishima YA, et al. Somatic inactivation of the PHD2 prolyl hydroxylase causes polycythemia and congestive heart failure. Blood. 2008; 111:3236-3244. [PubMed: 18096761]

113. Asada N, et al. Dysfunction of fibroblasts of extrarenal origin underlies renal fibrosis and renal anemia in mice. J. Clin. Invest. 2011; 121:3981-3990. [PubMed: 21911936]

114. Suzuki N, Hirano I, Pan X, Minegishi N, Yamamoto M. Erythropoietin production in neuroepithelial and neural crest cells during primitive erythropoiesis. Nat. Commun. 2013; 4:2902. [PubMed: 24309470]

115. Falke LL, Gholizadeh S, Goldschmeding R, Kok RJ, Nguyen TQ. Diverse origins of the myofibroblast-implications for kidney fibrosis. Nat. Rev. Nephrol. 2015; 11:233-244. [PubMed: 25584804]

116. Lin SL, Kisseleva T, Brenner DA, Duffield JS. Pericytes and perivascular fibroblasts are the primary source of collagen-producing cells in obstructive fibrosis of the kidney. Am. J. Pathol. 2008; 173:1617-1627. [PubMed: 19008372]

117. Little MH, McMahon AP. Mammalian kidney development: principles, progress, and projections. Cold Spring Harb. Perspect. Biol. 2012; 4:pii:a008300.

118. Kobayashi A, et al. Identification of a multipotent self-renewing stromal progenitor population during mammalian kidney organogenesis. Stem Cell Reports. 2014; 3:650-662. [PubMed: 25358792]

119. Liu J, et al. Cell-specific translational profiling in acute kidney injury. J. Clin. Invest. 2014; 124:1242-1254. [PubMed: 24569379]

120. Kurt B, et al. Deletion of von Hippel-Lindau protein converts renin-producing cells into erythropoietin-producing cells. J. Am. Soc. Nephrol. 2013; 24:433-444. [PubMed: 23393316]

121. Kurt B, Gerl K, Karger C, Schwarzensteiner I, Kurtz A. Chronic hypoxia-inducible transcription factor-2 activation stably transforms juxtaglomerular renin cells into fibroblast-like cells in vivo. J. Am. Soc. Nephrol. 2014; 26:587-596. [PubMed: 25071089]

122. Humphreys BD, et al. Fate tracing reveals the pericyte and not epithelial origin of myofibroblasts in kidney fibrosis. Am. J. Pathol. 2009; 176:85-97. [PubMed: 20008127]

123. Dame C, et al. Hepatic erythropoietin gene regulation by GATA-4. J. Biol. Chem. 2004; 279:2955-2961. [PubMed: 14583613]

124. Fried W, Kilbridge T, Krantz S, McDonald TP, Lange RD. Studies on extrarenal erythropoietin. J. Lab. Clin. Med. 1969; 73:244-248. [PubMed: 5764021]

125. Fried W. The liver as a source of extrarenal erythropoietin production. Blood. 1972; 40:671-677. [PubMed: 4637502]

126. Koury ST, Bondurant MC, Koury MJ, Semenza GL. Localization of cells producing erythropoietin in murine liver by in situ hybridization. Blood. 1991; 77:2497-2503. [PubMed: 2039831]

127. Maxwell PH, et al. Expression of a homologously recombined erythopoietin-SV40 T antigen fusion gene in mouse liver: evidence for erythropoietin production by Ito cells. Blood. 1994; 84:1823-1830. [PubMed: 8080987]

128. Querbes W, et al. Treatment of erythropoietin deficiency in mice with systemically administered siRNA. Blood. 2012; 120:1916-1922. [PubMed: 22611156]

129. Minamishima YA, Kaelin WG Jr. Reactivation of hepatic EPO synthesis in mice after PHD loss. Science. 2010; 329:407. [PubMed: 20651146]

130. Fandrey J, Bunn HF. In vivo and in vitro regulation of erythropoietin mRNA: measurement by competitive polymerase chain reaction. Blood. 1993; 81:617-623. [PubMed: 8381307]

131. Marti HH, et al. Erythropoietin gene expression in human, monkey and murine brain. Eur. J. Neurosci. 1996; 8:666-676. [PubMed: 9081618] 
132. Marti HH, et al. Detection of erythropoietin in human liquor: intrinsic erythropoietin production in the brain. Kidney Int. 1997; 51:416-418. [PubMed: 9027715]

133. Dame C, et al. Erythropoietin mRNA expression in human fetal and neonatal tissue. Blood. 1998; 92:3218-3225. [PubMed: 9787158]

134. Yasuda $Y$, et al. Estrogen-dependent production of erythropoietin in uterus and its implication in uterine angiogenesis. J. Biol. Chem. 1998; 273:25381-25387. [PubMed: 9738005]

135. Bernaudin M, et al. Neurons and astrocytes express EPO mRNA: oxygen-sensing mechanisms that involve the redox-state of the brain. Glia. 2000; 30:271-278. [PubMed: 10756076]

136. Dame $\mathrm{C}$, et al. Erythropoietin gene expression in different areas of the developing human central nervous system. Brain Res. Dev. Brain Res. 2000; 125:69-74.

137. Masuda S, Kobayashi T, Chikuma M, Nagao M, Sasaki R. The oviduct produces erythropoietin in an estrogen- and oxygen-dependent manner. Am. J. Physiol. Endocrinol. Metab. 2000; 278:E1038-E1044. [PubMed: 10827006]

138. Magnanti M, et al. Erythropoietin expression in primary rat Sertoli and peritubular myoid cells. Blood. 2001; 98:2872-2874. [PubMed: 11675366]

139. Kobayashi T, Yanase H, Iwanaga T, Sasaki R, Nagao M. Epididymis is a novel site of erythropoietin production in mouse reproductive organs. Biochem. Biophys. Res. Commun. 2002; 296:145-151. [PubMed: 12147241]

140. Bodo E, et al. Human hair follicles are an extrarenal source and a nonhematopoietic target of erythropoietin. FASEB J. 2007; 21:3346-3354. [PubMed: 17540710]

141. Miro-Murillo M, et al. Acute $V h l$ gene inactivation induces cardiac HIF-dependent erythropoietin gene expression. PLoS ONE. 2011; 6:e22589. [PubMed: 21811636]

142. Rankin EB, et al. The HIF signaling pathway in osteoblasts directly modulates erythropoiesis through the production of EPO. Cell. 2012; 149:63-74. [PubMed: 22464323]

143. Weidemann A, et al. The glial cell response is an essential component of hypoxia-induced erythropoiesis in mice. J. Clin. Invest. 2009; 119:3373-3383. [PubMed: 19809162]

144. Jelkmann W. Erythropoietin after a century of research: younger than ever. Eur. J. Haematol. 2007; 78:183-205. [PubMed: 17253966]

145. Franke K, et al. HIF-1a is a protective factor in conditional PHD2-deficient mice suffering from severe HIF-2a-induced excessive erythropoiesis. Blood. 2013; 121:1436-1445. [PubMed: 23264599]

146. Jelkmann W. Erythropoietin: structure, control of production, and function. Physiol. Rev. 1992; 72:449-489. [PubMed: 1557429]

147. Chiang CK, Tanaka T, Inagi R, Fujita T, Nangaku M. Indoxyl sulfate, a representative uremic toxin, suppresses erythropoietin production in a HIF-dependent manner. Lab. Invest. 2011; 91:1564-1571. [PubMed: 21863063]

148. Sakoda $Y$, et al. Herpesvirus entry mediator regulates hypoxia-inducible factor-1a and erythropoiesis in mice. J. Clin. Invest. 2011; 121:4810-4819. [PubMed: 22080867]

149. Boutin AT, et al. Epidermal sensing of oxygen is essential for systemic hypoxic response. Cell. 2008; 133:223-234. [PubMed: 18423195]

150. Evans RG, Gardiner BS, Smith DW, O'Connor PM. Intrarenal oxygenation: unique challenges and the biophysical basis of homeostasis. Am. J. Physiol. Renal Physiol. 2008; 295:F1259_ F1270. [PubMed: 18550645]

151. Paus R, Bodo E, Kromminga A, Jelkmann W. Erythropoietin and the skin: a role for epidermal oxygen sensing? Bioessays. 2009; 31:344-348. [PubMed: 19260015]

152. von Wussow U, Klaus J, Pagel H. Is the renal production of erythropoietin controlled by the brain stem? Am. J. Physiol. Endocrinol. Metab. 2005; 289:E82-E86. [PubMed: 15727951]

153. Eckardt KU, Kurtz A, Bauer C. Regulation of erythropoietin production is related to proximal tubular function. Am. J. Physiol. 1989; 256:F942-F947. [PubMed: 2719123]

154. Nangaku M, Eckardt KU. Pathogenesis of renal anemia. Semin. Nephrol. 2006; 26:261-268. [PubMed: 16949463]

155. Erslev AJ. Erythropoietin. N. Engl. J. Med. 1991; 324:1339-1344. [PubMed: 2017231] 
156. Duarte ME, Carvalho EF, Cruz EA, Lucena SB, Andress DL. Cytokine accumulation in osteitis fibrosa of renal osteodystrophy. Braz. J. Med. Biol. Res. 2002; 35:25-29. [PubMed: 11743611]

157. Santos FR, Moyses RM, Montenegro FL, Jorgetti V, Noronha IL. IL-1 $\beta$, TNF- $\alpha$, TGF- $\beta$, and bFGF expression in bone biopsies before and after parathyroidectomy. Kidney Int. 2003; 63:899907. [PubMed: 12631070]

158. Baer AN, Dessypris EN, Goldwasser E, Krantz SB. Blunted erythropoietin response to anaemia in rheumatoid arthritis. Br. J. Haematol. 1987; 66:559-564. [PubMed: 3663512]

159. Miller CB, Jones RJ, Piantadosi S, Abeloff MD, Spivak JL. Decreased erythropoietin response in patients with the anemia of cancer. N. Engl. J. Med. 1990; 322:1689-1692. [PubMed: 2342534]

160. Frede S, Fandrey J, Pagel H, Hellwig T, Jelkmann W. Erythropoietin gene expression is suppressed after lipopolysaccharide or interleukin- $1 \beta$ injections in rats. Am. J. Physiol. 1997; 273:R1067-R1071. [PubMed: 9321887]

161. Weiss G, Goodnough LT. Anemia of chronic disease. N. Engl. J. Med. 2005; 352:1011-1023. [PubMed: 15758012]

162. Libregts SF, et al. Chronic IFN- $\gamma$ production in mice induces anemia by reducing erythrocyte life span and inhibiting erythropoiesis through an IRF-1/PU.1 axis. Blood. 2011; 118:2578-2588. [PubMed: 21725055]

163. Dai CH, Price JO, Brunner T, Krantz SB. Fas ligand is present in human erythroid colonyforming cells and interacts with Fas induced by interferon $\gamma$ to produce erythroid cell apoptosis. Blood. 1998; 91:1235-1242. [PubMed: 9454753]

164. Felli N, et al. Multiple members of the TNF superfamily contribute to IFN- $\gamma$-mediated inhibition of erythropoiesis. J. Immunol. 2005; 175:1464-1472. [PubMed: 16034083]

165. Suehiro Y, et al. A novel mechanism in suppression of erythropoiesis during inflammation: a crucial role of RCAS1. Eur. J. Haematol. 2005; 74:365-373. [PubMed: 15813909]

166. Nemeth E, et al. IL-6 mediates hypoferremia of inflammation by inducing the synthesis of the iron regulatory hormone hepcidin. J. Clin. Invest. 2004; 113:1271-1276. [PubMed: 15124018]

167. Besson-Fournier C, et al. Induction of activin B by inflammatory stimuli up-regulates expression of the iron-regulatory peptide hepcidin through Smad1/5/8 signaling. Blood. 2012; 120:431-439. [PubMed: 22611157]

168. Nemeth E, et al. Hepcidin regulates cellular iron efflux by binding to ferroportin and inducing its internalization. Science. 2004; 306:2090-2093. [PubMed: 15514116]

169. Skikne BS, Ahluwalia N, Fergusson B, Chonko A, Cook JD. Effects of erythropoietin therapy on iron absorption in chronic renal failure. J. Lab. Clin. Med. 2000; 135:452-458. [PubMed: 10850644]

170. Sargent JA, Acchiardo SR. Iron requirements in hemodialysis. Blood Purif. 2004; 22:112-123. [PubMed: 14732819]

171. Kalantar-Zadeh K, Streja E, Miller JE, Nissenson AR. Intravenous iron versus erythropoiesisstimulating agents: friends or foes in treating chronic kidney disease anemia? Adv. Chronic Kidney Dis. 2009; 16:143-151. [PubMed: 19233073]

172. Besarab A, Coyne DW. Iron supplementation to treat anemia in patients with chronic kidney disease. Nat. Rev. Nephrol. 2010; 6:699-710. [PubMed: 20956992]

173. Macdougall IC, et al. A randomized controlled study of iron supplementation in patients treated with erythropoietin. Kidney Int. 1996; 50:1694-1699. [PubMed: 8914038]

174. Fudin R, Jaichenko J, Shostak A, Bennett M, Gotloib L. Correction of uremic iron deficiency anemia in hemodialyzed patients: a prospective study. Nephron. 1998; 79:299-305. [PubMed: 9678430]

175. Kautz L, et al. Identification of erythroferrone as an erythroid regulator of iron metabolism. Nat. Genet. 2014; 46:678-684. [PubMed: 24880340]

176. Pantopoulos K. Iron metabolism and the IRE/IRP regulatory system: an update. Ann. N. Y. Acad. Sci. 2004; 1012:1-13. [PubMed: 15105251]

177. Rouault TA. The role of iron regulatory proteins in mammalian iron homeostasis and disease. Nat. Chem. Biol. 2006; 2:406-414. [PubMed: 16850017] 
178. Cianetti L, et al. Expression of alternative transcripts of ferroportin-1 during human erythroid differentiation. Haematologica. 2005; 90:1595-1606. [PubMed: 16330432]

179. Zhang DL, Hughes RM, Ollivierre-Wilson H, Ghosh MC, Rouault TA. A ferroportin transcript that lacks an iron-responsive element enables duodenal and erythroid precursor cells to evade translational repression. Cell. Metab. 2009; 9:461-473. [PubMed: 19416716]

180. Zhang DL, et al. Hepcidin regulates ferroportin expression and intracellular iron homeostasis of erythroblasts. Blood. 2011; 118:2868-2877. [PubMed: 21700773]

181. Ghosh MC, et al. Deletion of iron regulatory protein 1 causes polycythemia and pulmonary hypertension in mice through translational derepression of HIF2a. Cell. Metab. 2013; 17:271281. [PubMed: 23395173]

182. Anderson SA, et al. The IRP1-HIF-2a axis coordinates iron and oxygen sensing with erythropoiesis and iron absorption. Cell. Metab. 2013; 17:282-290. [PubMed: 23395174]

183. Wilkinson N, Pantopoulos K. IRP1 regulates erythropoiesis and systemic iron homeostasis by controlling HIF2a mRNA translation. Blood. 2013; 122:1658-1668. [PubMed: 23777768]

184. Singh AK, et al. Correction of anemia with epoetin alfa in chronic kidney disease. N. Engl. J. Med. 2006; 355:2085-2098. [PubMed: 17108343]

185. Drueke TB, et al. Normalization of hemoglobin level in patients with chronic kidney disease and anemia. N. Engl. J. Med. 2006; 355:2071-2084. [PubMed: 17108342]

186. Besarab A, et al. The effects of normal as compared with low hematocrit values in patients with cardiac disease who are receiving hemodialysis and epoetin. N. Engl. J. Med. 1998; 339:584590. [PubMed: 9718377]

187. Besarab A, Frinak S, Yee J. What is so bad about a hemoglobin level of 12 to $13 \mathrm{~g} / \mathrm{dl}$ for chronic kidney disease patients anyway? Adv. Chronic Kidney Dis. 2009; 16:131-142. [PubMed: 19233072]

188. Boudville NC, et al. Hemoglobin variability in nondialysis chronic kidney disease: examining the association with mortality. Clin. J. Am. Soc. Nephrol. 2009; 4:1176-1182. [PubMed: 19423567]

189. Pfeffer MA, et al. A trial of darbepoetin alfa in type 2 diabetes and chronic kidney disease. N. Engl. J. Med. 2009; 361:2019-2032. [PubMed: 19880844]

190. Goldberg MA, Glass GA, Cunningham JM, Bunn HF. The regulated expression of erythropoietin by two human hepatoma cell lines. Proc. Natl Acad. Sci. USA. 1987; 84:7972-7976. [PubMed: 2825172]

191. Schuster SJ, et al. Stimulation of erythropoietin gene transcription during hypoxia and cobalt exposure. Blood. 1989; 73:13-16. [PubMed: 2910354]

192. Goldberg MA, Gaut CC, Bunn HF. Erythropoietin mRNA levels are governed by both the rate of gene transcription and posttranscriptional events. Blood. 1991; 77:271-277. [PubMed: 1985693]

193. Wang GL, Semenza GL. Desferrioxamine induces erythropoietin gene expression and hypoxiainducible factor 1 DNA-binding activity: implications for models of hypoxia signal transduction. Blood. 1993; 82:3610-3615. [PubMed: 8260699]

194. Wang GL, Semenza GL. General involvement of hypoxia-inducible factor 1 in transcriptional response to hypoxia. Proc. Natl Acad. Sci. USA. 1993; 90:4304-4308. [PubMed: 8387214]

195. Goldwasser E, Jacobson LO, Fried W, Plzak L. Mechanism of the erythropoietic effect of cobalt. Science. 1957; 125:1085-1086. [PubMed: 13432762]

196. Goldwasser E, Jacobson LO, Fried W, Plzak LF. Studies on erythropoiesis. V. The effect of cobalt on the production of erythropoietin. Blood. 1958; 13:55-60. [PubMed: 13499580]

197. Edwards MS, Curtis JR. Use of cobaltous chloride in anaemia of maintenance hemodialysis patients. Lancet. 1971; 2:582-583. [PubMed: 4106108]

198. Ebert B, Jelkmann W. Intolerability of cobalt salt as erythropoietic agent. Drug Test. Anal. 2014; 6:185-189. [PubMed: 24039233]

199. Vengellur A, Phillips JM, Hogenesch JB, LaPres JJ. Gene expression profiling of hypoxia signaling in human hepatocellular carcinoma cells. Physiol. Genomics. 2005; 22:308-318. [PubMed: 15942021] 
200. Vengellur A, Woods BG, Ryan HE, Johnson RS, LaPres JJ. Gene expression profiling of the hypoxia signaling pathway in hypoxia-inducible factor 1a null mouse embryonic fibroblasts. Gene Expr. 2003; 11:181-197. [PubMed: 14686790]

201. Jefferson JA, et al. Excessive erythrocytosis, chronic mountain sickness, and serum cobalt levels. Lancet. 2002; 359:407-408. [PubMed: 11844517]

202. Barrett TD, et al. Pharmacological characterization of 1-(5-chloro-6-(trifluoromethoxy)-1Hbenzoimidazol-2-yl)-1H-pyrazole-4-carboxylic acid (JNJ-42041935), a potent and selective hypoxia-inducible factor prolyl hydroxylase inhibitor. Mol. Pharmacol. 2011; 79:910-920. [PubMed: 21372172]

203. Loenarz C, Schofield CJ. Physiological and biochemical aspects of hydroxylations and demethylations catalyzed by human 2-oxoglutarate oxygenases. Trends Biochem. Sci. 2011; 36:7-18. [PubMed: 20728359]

204. Akebia Therapeutics. Publications: abstracts, posters and presentations. 2015. akebia.com [online], http://akebia.com/media/publications/

205. FibroGen. Publications. 2015. fibrogen.com [online], http://www.fibrogen.com/publications/

206. GlaxoSmithKline. Studies filtered by compound GSK1278863.. GSK Clinical Study Register [online]. 2015. http://www.gsk-clinicalstudyregister.com/compounds/gsk1278863\#ps

207. Bernhardt WM, et al. Inhibition of prolyl hydroxylases increases erythropoietin production in ESRD. J. Am. Soc. Nephrol. 2010; 21:2151-2156. [PubMed: 21115615]

208. Haase VH. Hypoxia-inducible factors in the kidney. Am. J. Physiol. Renal Physiol. 2006; 291:F271-F281. [PubMed: 16554418]

209. Haase VH. Pathophysiological consequences of HIF activation: HIF as a modulator of fibrosis. Ann. N. Y. Acad. Sci. 2009; 1177:57-65. [PubMed: 19845607]

210. Semenza GL. Oxygen sensing, hypoxia-inducible factors, and disease pathophysiology. Annu. Rev. Pathol. 2014; 9:47-71. [PubMed: 23937437]

211. Hickey MM, et al. The von Hippel-Lindau Chuvash mutation promotes pulmonary hypertension and fibrosis in mice. J. Clin. Invest. 2010; 120:827-839. [PubMed: 20197624]

212. Cowburn AS, et al. HIF isoforms in the skin differentially regulate systemic arterial pressure. Proc. Natl Acad. Sci. USA. 2013; 110:17570-17575. [PubMed: 24101470]

213. Shimoda LA, Laurie SS. HIF and pulmonary vascular responses to hypoxia. J. Appl. Physiol. 1985; 2014; 116:867-874. [PubMed: 24336881]

214. Bertout JA, Patel SA, Simon MC. The impact of $\mathrm{O}_{2}$ availability on human cancer. Nat. Rev. Cancer. 2008; 8:967-975. [PubMed: 18987634]

215. Keith B, Johnson RS, Simon MC. HIF1a and HIF2a: sibling rivalry in hypoxic tumour growth and progression. Nat. Rev. Cancer. 2012; 12:9-22. [PubMed: 22169972]

216. Semenza GL. HIF-1 mediates metabolic responses to intratumoral hypoxia and oncogenic mutations. J. Clin. Invest. 2013; 123:3664-3671. [PubMed: 23999440]

217. Krock BL, Skuli N, Simon MC. Hypoxia-induced angiogenesis: good and evil. Genes Cancer. 2011; 2:1117-1133. [PubMed: 22866203]

218. Astellas Pharma Inc.. News release: the FDA accepts the complete response for clinical holds of FG-2216*/FG-4592 for the treatment of anemia. 2008. astellas.com [online], http:// www.astellas.com/en/corporate/news/pdf/080402_eg.pdf

219. Rabinowitz MH. Inhibition of hypoxia-inducible factor prolyl hydroxylase domain oxygen sensors: tricking the body into mounting orchestrated survival and repair responses. J. Med. Chem. 2013; 56:9369-9402. [PubMed: 23977883]

220. Hong YR, et al. [(4-Hydroxyl-benzo[4, 5] thieno[3, 2-c]pyridine-3-carbonyl)-amino]-acetic acid derivatives; HIF prolyl 4-hydroxylase inhibitors as oral erythropoietin secretagogues. Bioorg Med. Chem. Lett. 2013; 23:5953-5957. [PubMed: 24042008]

221. Klaus S, Langsetmo I, Neff T, Lin A, Liu D. beneficial pharmacodynamic effects resulting from 'complete erythropoiesis' induced by novel HIF prolyl hydroxylase inhibitors FG-2216 and FG-4592 [abstract]. J. Am. Soc. Nephrol. 2008; 19:524A. 
222. Besarab A, Szczech L, Yu KHP, Neff NB. Impact of iron regimen on iron indices and hepcidin during roxadustat anemia correction in incident dialysis patients [abstract]. J. Am. Soc. Nephrol. 2014; 25:304A.

223. Frohna PA, et al. Preliminary results from a randomized, single-blind, placebo-controlled trial of FG-4592, a novel hypoxia inducible factor prolyl hydroxylase inhibitor, in subjects with CKD anemia [abstract]. J. Am. Soc. Nephrol. 2007; 18:763A.

224. Provenzano R, et al. FG-4592, a novel oral hypoxia-inducible factor prolyl hydroxylase inhibitor (HIF-PHI), maintains hemoglobin levels and lowers cholesterol in hemodialysis (HD) patients: phase 2 comparison with epoetin alfa [abstract]. J. Am. Soc. Nephrol. 2012; 23:428A.

225. Hsieh MM, et al. HIF prolyl hydroxylase inhibition results in endogenous erythropoietin induction, erythrocytosis, and modest fetal hemoglobin expression in rhesus macaques. Blood. 2007; 110:2140-2147. [PubMed: 17557894]

226. Kindler J, et al. Single-dose pharmacokinetics of recombinant human erythropoietin in patients with various degrees of renal failure. Nephrol. Dial. Transplant. 1989; 4:345-349. [PubMed: 2505184]

227. Kapitsinou PP, et al. Preischemic targeting of HIF prolyl hydroxylation inhibits fibrosis associated with acute kidney injury. Am. J. Physiol. Renal Physiol. 2012; 302:F1172-F1179. [PubMed: 22262480]

228. Brigandi RA, et al. The prolyl hydroxylase inhibitor, GSK1278863A, induced EPO in vitro and efficient erythropoiesis leading to increased hemoglobin in vivo [abstract]. J. Am. Soc. Nephrol. 2010; 21:722A.

229. Brigandi RA, et al. Prolylhydroxylase inhibitor modulation of erythropoietin in a randomized placebo controlled trial [abstract]. J. Am. Soc. Nephrol. 2010; 21:390A. [PubMed: 20133481]

230. Brigandi RA, et al. Induction of erythropoiesis in anemic patients by prolylhydroxylase inhibitor in a repeat dose, randomized placebo controlled trial [abstract]. J. Am. Soc. Nephrol. 2012; 23:662A.

231. Olson E, et al. Short-term treatment with a novel HIF-prolyl hydroxylase inhibitor (GSK1278863) failed to improve measures of performance in subjects with claudication-limited peripheral artery disease. Vasc. Med. 2014; 19:473-482. [PubMed: 25377872]

232. Shalwitz R, Hartman C, Flinn C, Shalwitz I, Logan DK. AKB-6548, a novel hypoxia-inducible factor prolyl hydroxylase inhibitor reduces hepcidin and ferritin while it increases reticulocyte production and total iron binding capacity in healthy adults [abstract]. J. Am. Soc. Nephrol. $2011 ; 22: 45$ A.

233. Hartman C, et al. AKB-6548, a new hypoxia-inducible factor prolyl hydroxylase inhibitor increases hemoglobin while decreasing ferritin in a 28 -day, phase 2 a dose escalation study in stage 3 and 4 chronic kidney disease patients with anemia [abstract]. J. Am. Soc. Nephrol. 2011; 22:435A.

234. Shalwitz R, et al. AKB-6548: A new hypoxia-inducible factor prolyl hydroxylase inhibitor, increases hemoglobin in chronic kidney disease patients without increasing basal erythropoietin levels [abstract]. J. Am. Soc. Nephrol. 2012; 23:56A.

235. Hartman, CS., et al. Phase 2 study of AKB-6548, a novel hypoxia-inducible factor prolylhydroxylase inhibitor (HIF-PHI) in patients with end stage renal disease (ESRD) undergoing hemodialysis (HD). 2014. akebia.com [online], http://akebia.com/wp-content/themes/akebia/img/ media-kit/abstracts-posters-presentations/20141106_Akebia_ASN_Informational_PosterFINAL.pdf

236. Jefferson JA, et al. Hyperuricemia, hypertension, and proteinuria associated with high-altitude polycythemia. Am. J. Kidney Dis. 2002; 39:1135-1142. [PubMed: 12046023]

237. Baillie JK, et al. Endogenous urate production augments plasma antioxidant capacity in healthy lowland subjects exposed to high altitude. Chest. 2007; 131:1473-1478. [PubMed: 17494796]

238. Flamme I, et al. Mimicking hypoxia to treat anemia: HIF-stabilizer BAY 85-3934 (molidustat) stimulates erythropoietin production without hypertensive effects. PLoS ONE. 2014; 9:e111838. [PubMed: 25392999]

239. Boettcher M-F, et al. First-in-man Study with BAY 85-3934-a new oral selective HIF-PH inhibitor for the treatment of renal anemia. J. Am. Soc. Nephrol. 2013; 24:347A. 
240. McMahon S, Grondin F, McDonald PP, Richard DE, Dubois CM. Hypoxia-enhanced expression of the proprotein convertase furin is mediated by hypoxia-inducible factor-1: impact on the bioactivation of proproteins. J. Biol. Chem. 2005; 280:6561-6569. [PubMed: 15611046]

241. Silvestri L, Pagani A, Camaschella C. Furin-mediated release of soluble hemojuvelin: a new link between hypoxia and iron homeostasis. Blood. 2008; 111:924-931. [PubMed: 17938254]

242. Silvestri L, et al. The serine protease matriptase-2 (TMPRSS6) inhibits hepcidin activation by cleaving membrane hemojuvelin. Cell. Metab. 2008; 8:502-511. [PubMed: 18976966]

243. Du X, et al. The serine protease TMPRSS6 is required to sense iron deficiency. Science. 2008; 320:1088-1092. [PubMed: 18451267]

244. Lakhal S, et al. Regulation of type II transmembrane serine proteinase TMPRSS6 by hypoxiainducible factors: new link between hypoxia signaling and iron homeostasis. J. Biol. Chem. 2010; 286:4090-4097. [PubMed: 20966077]

245. Macdougall IC. Role of uremic toxins in exacerbating anemia in renal failure. Kidney Int. Suppl. 2001; 78:S67-S72. [PubMed: 11168986] 


\section{Key points}

The hypoxia-inducible factor (HIF) oxygen-sensing pathway has a central role in regulating erythropoiesis; it mediates the hypoxic induction of erythropoietin and coordinates erythropoietin and erythrocyte production with iron metabolism

- Peritubular renal interstitial fibroblast-like cells and pericytes synthesize erythropoietin in an oxygen-regulated and HIF-2-dependent manner; they lose their ability to produce erythropoietin as they transdifferentiate into myofibroblasts following kidney injury

In anaemia associated with renal disease, erythropoiesis is suppressed due to the combined and interrelated effects of erythropoietin deficiency, inflammatory cytokines and iron deficiency

The pharmacologic activation of hypoxia responses with HIF stabilizers provides a physiologic and comprehensive approach to the treatment of renal anaemia and warrants large, long-term clinical safety and efficacy trials 


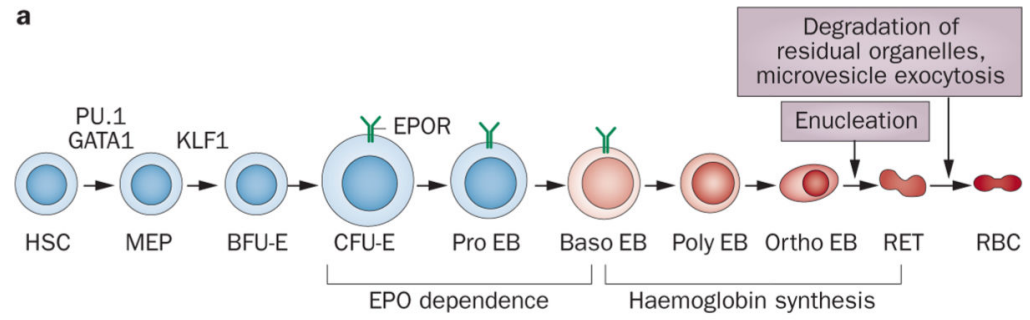

b

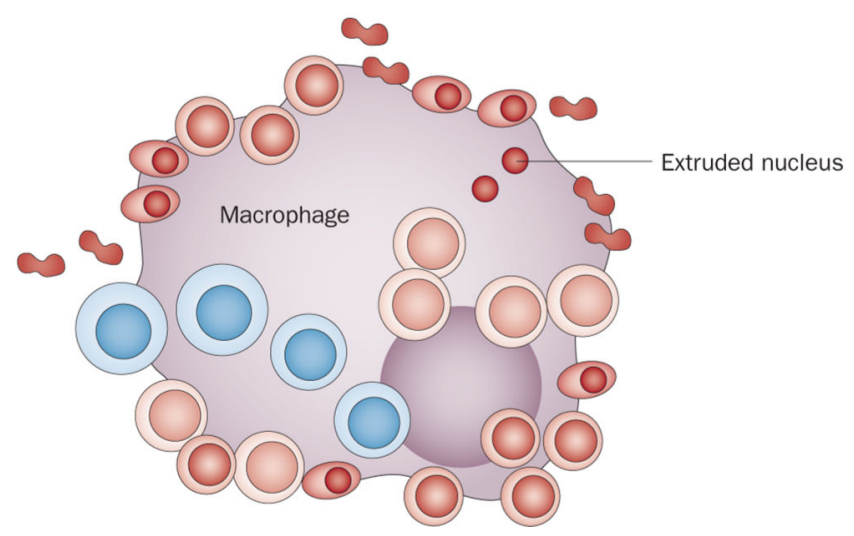

Figure 1.

Overview of erythropoiesis. a Progressive stages of erythroid differentiation showing the relative sizes and presumed or known morphologic appearances of haematopoietic cells at various stages. The transcription factors PU.1 and GATA1 are important in determining whether HSCs will progress towards an erythroid or a non-erythroid fate, whereas KLF1 is important in determining whether MEPs will progress towards an erythroid or a megakaryocytic fate. PU.1 expression continues until the EPO-dependent stages, whereas GATA1 and KLF1 have important roles in differentiation throughout haemoglobin synthesis. Stages of haemoglobin synthesis show relative accumulations of haemoglobin as increasing intensity of red in the cytoplasm. The periods of EPO dependence ending at the early Baso EB stage and haemoglobin synthesis beginning in the late Baso EB stage do not overlap. b | An erythroblastic island. Erythroid cells from the CFU-E through to the RET stages are attached to a central macrophage. RETs detach from the macrophage before leaving the marrow and entering the blood. Two extruded nuclei created when RETs are formed from Ortho EBs are shown inside the central macrophage where they have been phagocytosed and will be degraded. Abbreviations: Baso, basophilic; BFU-E, burst-forming unit-erythroid; CFU-E, colony-forming unit-erythroid; EB, erythroblast; EPO, erythropoietin; EPOR, EPO receptor; HSC, pluripotent haematopoietic stem cell; MEP, bipotent megakaryocytic-erythroid progenitor; Ortho, orthochromatic; Poly, polychromatophilic; RBC, erythrocyte; RET, reticulocyte. 


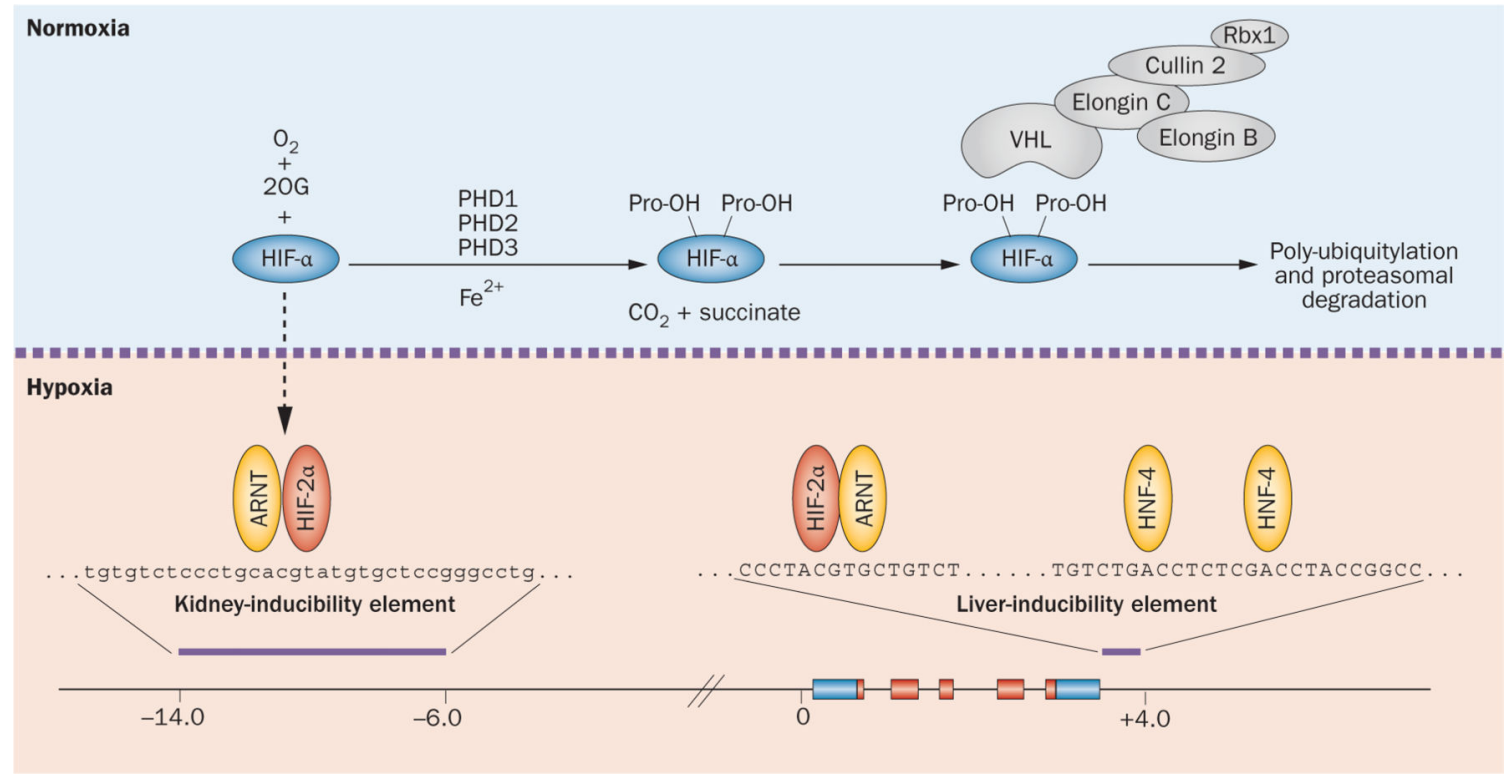

Figure 2.

Regulation of HIF degradation by PHDs and hypoxic induction of erythropoietin. HIF controls a wide spectrum of tissue-specific and systemic hypoxia responses, with HIF-2 being the principal regulator of EPO transcription in vivo. The HIF oxygen-sensing machinery targets HIF-1a, HIF-2a and HIF-3a for proteasomal degradation by the VHLE3-ubiquitin ligase complex. In the presence of oxygen HIF-a is hydroxylated at specific proline residues (Pro-OH) by PHD enzymes. Hydroxylation of HIF-a permits binding to the $\beta$-domain of VHL, which functions as the substrate recognition component of the VHL-E3ubiquitin ligase complex. Under hypoxic conditions, HIF-a degradation is inhibited and HIF-a translocates to the nucleus, where it forms a heterodimer with ARNT and binds hypoxia regulatory elements in EPO, which contain the HIF consensus binding site 5'$R C G T G-3 '$. The hypoxic induction of $E P O$ in the liver is mediated by the liver-inducibility element in the 3'-end of the $E P O$ gene, whereas the hypoxic induction of renal $E P O$ requires the kidney inducibility element located upstream of the EPO transcription start site. The putative DNA sequence of the kidney inducibility element is shown in lower case letters. HNF-4 is an important coregulator of EPO. Boxes depict EPO exons. EPO coding sequences and non-translated sequences are depicted in red and blue, respectively. The distance from the EPO transcription start site is indicated in kilobases. Abbreviations: 2OG, 2-oxoglutarate; ARNT, aryl hydrocarbon receptor nuclear translocator; EPO, erythropoietin gene; $\mathrm{Fe}^{2+}$, ferrous iron; $\mathrm{HIF}$, hypoxia-inducible factor; $\mathrm{HNF}-4$, hepatocyte nuclear factor 4; PHD, prolyl-4-hydroxylase domain. 


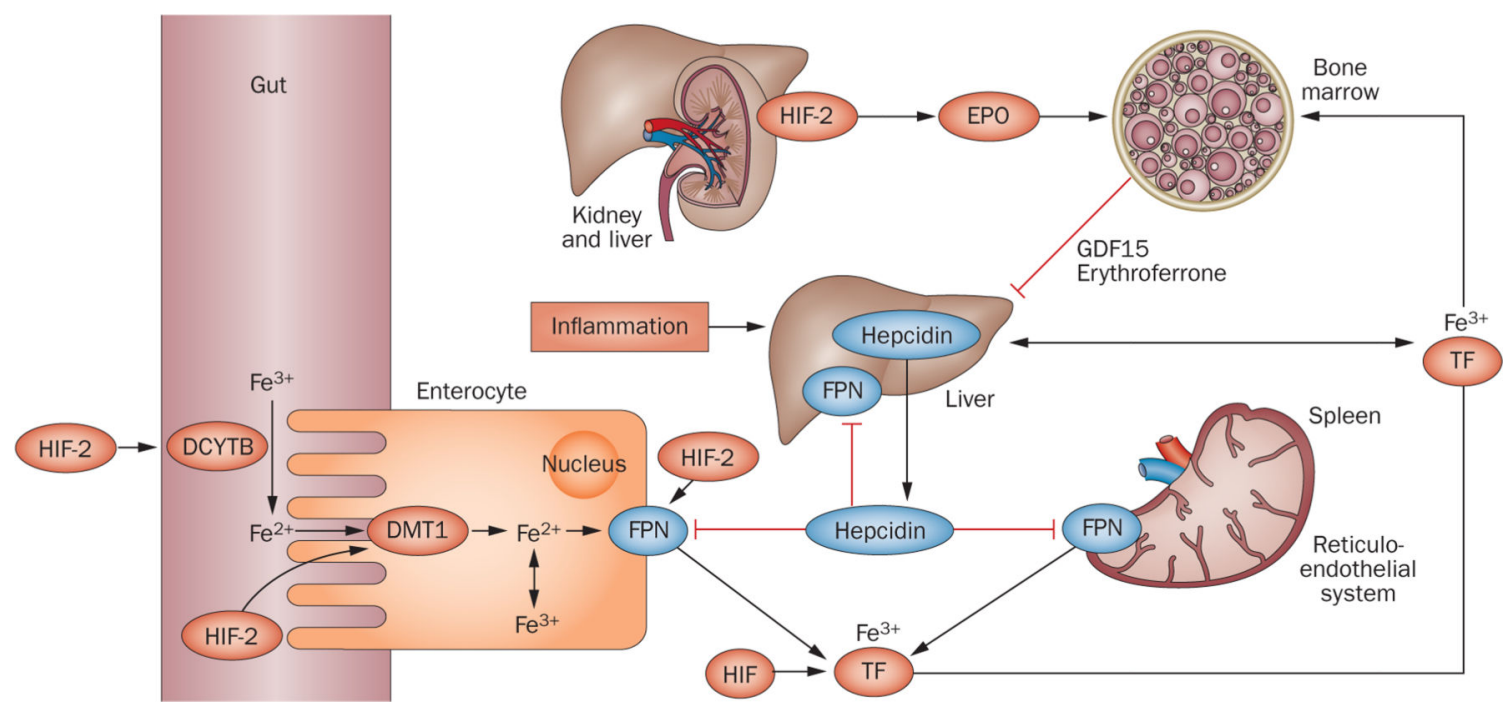

Figure 3.

HIF coordinates erythropoietin production with iron metabolism. HIF-2 stimulates renal and hepatic erythropoietin synthesis, which raises serum erythropoietin levels, stimulating erythropoiesis in the bone marrow. In the duodenum, DCYTB reduces $\mathrm{Fe}^{3+}$ to $\mathrm{Fe}^{2+}$, which then enters enterocytes via DMT1. DCYTB and DMT1 are both regulated by HIF-2. Iron is then released into the circulation via FPN, which is also HIF-2-inducible. In the circulation iron is transported in a complex with TF to the liver, bone marrow and other organs; cells of the reticuloendothelial system acquire iron through the phagocytosis of senescent red cells. TF is HIF-regulated, and hypoxia and/or pharmacologic PHD inhibition raises TF serum levels. Increased erythropoietic activity in the bone marrow produces GDF15 and erythroferrone, which suppress hepcidin in hepatocytes. Hepcidin suppression increases FPN expression on enterocytes, hepatocytes and macrophages, resulting in increased iron absorption and mobilization from internal stores. Inflammation stimulates hepcidin production in the liver and leads to reduced FPN expression and hypoferraemia. In addition to regulating hepcidin indirectly by stimulating erythropoiesis, in vitro studies suggest that HIF might also modulate hepcidin expression through the regulation of furin and transmembrane protease serine 6. ${ }^{240-244}$ Abbreviations: DCYTB, duodenal cytochrome $b$ reductase 1; DMT1, divalent metal transporter-1; EPO, plasma erythropoietin; $\mathrm{Fe}^{2+}$, ferrous iron; $\mathrm{Fe}^{3+}$, ferric iron; FPN, ferroportin; GDF15, growth differentiation factor 15; HIF, hypoxia-inducible factor; $\mathrm{TF}$, transferrin. 
a

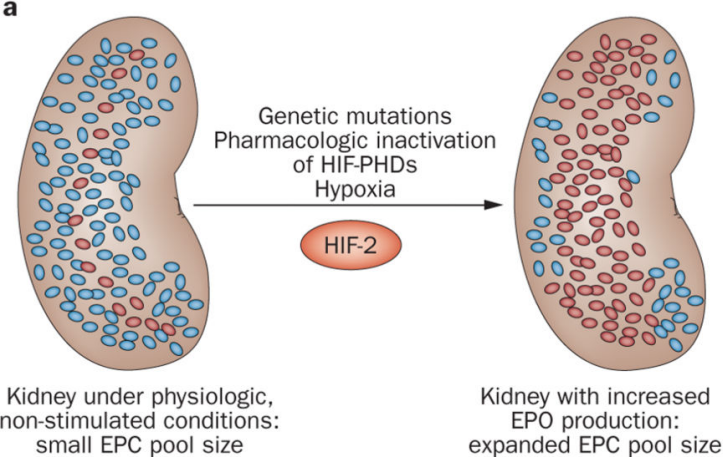

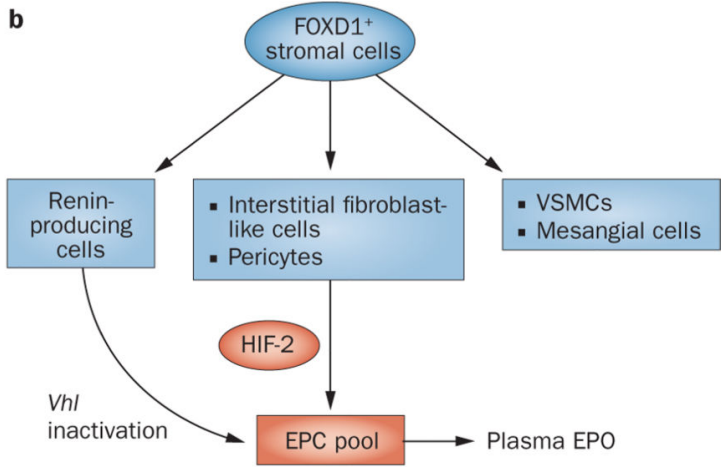

Figure 4.

The number of EPCs regulates renal erythropoietin output. a | Under physiologic, nonstimulated conditions a small number of renal EPCs are responsible for renal erythropoietin output. The size of the EPC pool is regulated in an oxygen-dependent manner and increases under hypoxic conditions. The expansion of the EPC pool requires HIF-2 signalling, which is activated by hypoxia, pharmacologic PHD inhibition, or as a consequence of mutations in the oxygen-sensing pathway. b | Renal EPCs are derived from FOXD1-expressing stromal cells, and include interstitial fibroblast-like cells, pericytes and renin-producing cells. Reninproducing cells can be induced to synthesize erythropoietin under conditions of $V h l$ gene inactivation; their role in hypoxia-induced renal erythropoietin production is unclear. Abbreviations: EPC, erythropoietin-producing cell; EPO, erythropoietin; HIF-2, hypoxiainducible factor-2; VSMC, vascular smooth muscle cell. 


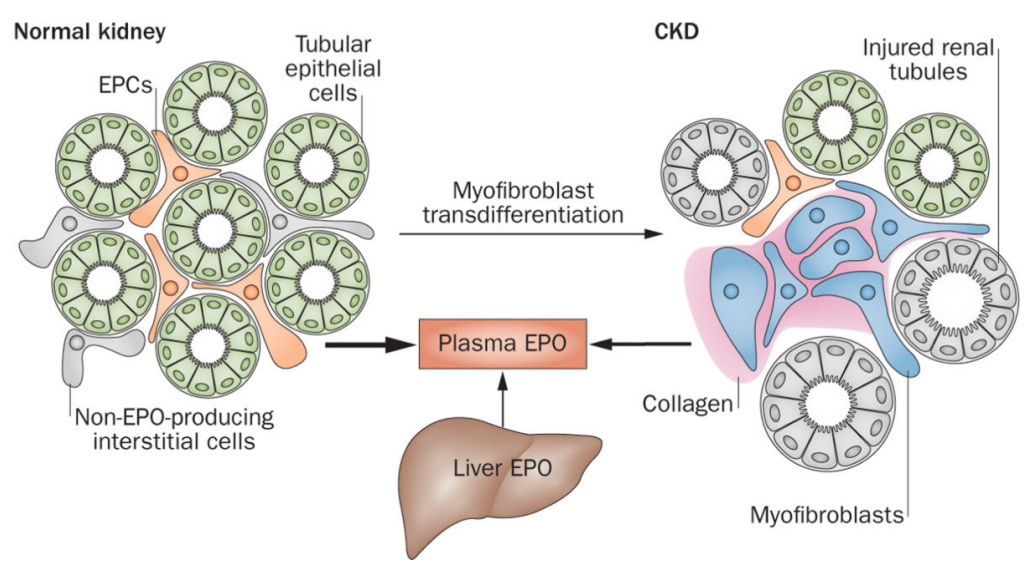

Figure 5.

Cellular basis of erythropoietin deficiency in renal failure. In the normal kidney, EPCs are recruited from peritubular interstitial fibroblast-like cells and pericytes. Tubular epithelial cells do not produce EPO. Under conditions of injury, EPCs or interstitial cells with EPC potential transdifferentiate into myofibroblasts, which synthesize collagen and lose their ability to produce EPO. In CKD, EPC recruitment is impaired, resulting in reduced renal EPO output and the development of anaemia. Under conditions of severe hypoxia or in patients with advanced CKD, the liver contributes to plasma EPO levels. Abbreviations: CKD, chronic kidney disease; EPC, erythropoietin-producing cell; EPO, erythropoietin. 


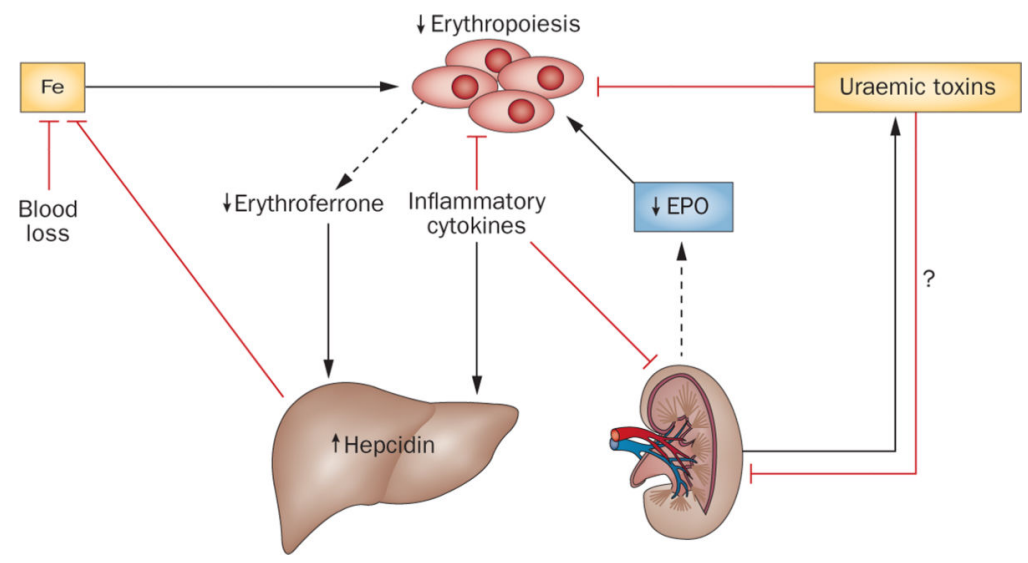

Figure 6.

Mechanisms of renal anaemia. In renal anaemia, the ability of the kidney to produce EPO is impaired. Inflammatory cytokines suppress erythropoiesis in the bone marrow, EPO production in the kidney, and stimulate hepcidin production in the liver, which negatively affects iron absorption and mobilization. Hepcidin is also maintained at higher levels by decreased erythroferrone production, which is secondary to a reduction in erythroblast numbers due to EPO deficiency. In patients with advanced CKD, the liver contributes significantly to plasma EPO levels. The contribution of uraemic toxins to the pathogenesis of renal anaemia is only poorly understood. Uraemic toxins have been shown to suppress erythroid colony formation in vitro as well as EPO transcription in hepatoma cells, the latter indicating possible suppressive effects on hepatic and renal EPO production in vivo. ${ }^{147,245}$ Abbreviations: CKD, chronic kidney disease; EPO, erythropoietin; Fe, iron. 


\section{Table 1}

HIF activators in clinical trials

\begin{tabular}{|c|c|c|}
\hline Compound (sponsor) & Trials registered with ClinicalTrials.gov ${ }^{*}$ & Study characteristics \\
\hline \multirow[t]{3}{*}{ AKB-6548 (Akebia Therapeutics) } & Healthy individuals: NCT02327546 & $\begin{array}{l}\text { Pharmacokinetic study to assess the effect of } \\
\text { ferrous sulphate on bioavailability of the } \\
\text { compound }\end{array}$ \\
\hline & $\begin{array}{l}\text { Nondialysis-dependent CKD: NCT01906489 } \\
\text { (completed November 2014) }\end{array}$ & $\begin{array}{l}\text { Phase II study to evaluate the haemoglobin } \\
\text { responses, safety and tolerability of } \\
\text { AKB-6548; } 210 \text { patients; dosing for } 20 \\
\text { weeks }\end{array}$ \\
\hline & Dialysis-dependent CKD: NCT02260193 & $\begin{array}{l}\text { Phase II study to evaluate the haemoglobin } \\
\text { responses, safety and tolerability of } \\
\text { AKB- } 6548 ; 60 \text { patients on HD; dosing for } \\
16 \text { weeks }\end{array}$ \\
\hline \multirow[t]{5}{*}{ BAY85-3934/Molidustat (Bayer) } & $\begin{array}{l}\text { Non-dialysis-dependent CKD: NCT02021370 } \\
\text { (Dialogue 1) }\end{array}$ & $\begin{array}{l}\text { Phase II safety and efficacy fixed-dose } \\
\text { correction study; } 120 \text { EPO-naive patients; } \\
\text { duration } 16 \text { weeks. }\end{array}$ \\
\hline & $\begin{array}{l}\text { Non-dialysis-dependent CKD: NCT02021409 } \\
\text { (Dialogue 2) }\end{array}$ & $\begin{array}{l}\text { Phase II safety and efficacy study; } 120 \\
\text { patients; duration } 16 \text { weeks; active } \\
\text { comparator darbepoetin alfa }\end{array}$ \\
\hline & $\begin{array}{l}\text { Non-dialysis-dependent CKD: NCT02055482 } \\
\text { (Dialogue 3) }\end{array}$ & $\begin{array}{l}\text { Phase II long-term safety and efficacy } \\
\text { extension study recruiting patients from } \\
\text { NCT02021370 and NCT02021409; } 240 \\
\text { patients; duration } \leq 36 \text { months }\end{array}$ \\
\hline & $\begin{array}{l}\text { Dialysis-dependent CKD: NCT01975818 } \\
\text { (Dialogue 4) }\end{array}$ & $\begin{array}{l}\text { Phase II safety and efficacy study; } 148 \\
\text { patients on HD who switched from ESA; } \\
\text { duration } 16 \text { weeks }\end{array}$ \\
\hline & $\begin{array}{l}\text { Dialysis-dependent CKD: NCT02064426 } \\
\text { (Dialogue 5) }\end{array}$ & $\begin{array}{l}\text { Phase II safety and efficacy long-term } \\
\text { extension study; } 148 \text { patients on HD from } \\
\text { parent study NCT01975818; duration } ₫ 6 \\
\text { months }\end{array}$ \\
\hline \multirow[t]{2}{*}{ DS-1093 (Daiichi Sankyo Inc.) } & Healthy males: NCT02142400 & $\begin{array}{l}\text { Phase I study to assess pharmacokinetics, } \\
\text { pharmacodynamics, safety and tolerability }\end{array}$ \\
\hline & $\begin{array}{l}\text { Non-dialysis and HD-dependent CKD: } \\
\text { NCT02299661 }\end{array}$ & $\begin{array}{l}\text { Pilot pharmacokinetic and } \\
\text { pharmacodynamic study }\end{array}$ \\
\hline \multirow[t]{7}{*}{$\begin{array}{l}\text { FG-4592/ASP1517/Roxadustat } \\
\text { (FibroGen in collaboration with Astellas } \\
\text { Pharma and AstraZeneca) }\end{array}$} & $\begin{array}{l}\text { Nondialysis-dependent CKD: NCT01964196 } \\
\text { (intermittent) }\end{array}$ & $\begin{array}{l}\text { Phase II safety and efficacy study of } \\
\text { switching from thrice weekly to once weekly } \\
\text { dosing }\end{array}$ \\
\hline & Nondialysis-dependent CKD: NCT01750190 & $\begin{array}{l}\text { Phase III safety and efficacy study; } 450 \\
\text { patients; duration } 52 \text { weeks }\end{array}$ \\
\hline & $\begin{array}{l}\text { Nondialysis-dependent CKD: NCT01887600 } \\
\text { (ALPS) }\end{array}$ & $\begin{array}{l}\text { Phase III safety and efficacy study; } 600 \\
\text { patients; treatment period 52-104 weeks }\end{array}$ \\
\hline & $\begin{array}{l}\text { Nondialysis-dependent CKD: NCT02021318 } \\
\text { (Dolomites) }\end{array}$ & $\begin{array}{l}\text { Phase III safety and efficacy study; } 570 \\
\text { patients; treatment period } 104 \text { weeks; active } \\
\text { comparator darbepoetin alfa }\end{array}$ \\
\hline & Nondialysis-dependent CKD: NCT02174627 & $\begin{array}{l}\text { Phase III safety, efficacy and cardiovascular } \\
\text { outcome study; } 2,600 \text { patients; event-driven } \\
\text { treatment period } \_ \text {years }\end{array}$ \\
\hline & $\begin{array}{l}\text { Nondialysis and dialysis-dependent CKD: } \\
\text { NCT01630889 (by invitation) }\end{array}$ & $\begin{array}{l}\text { Phase II and III observational study to } \\
\text { evaluate the long-term efficacy and safety of } \\
\text { FG- } 4592 ; 150 \text { patients with history of } \\
\text { previous completion of a FG- } 4592 \text { study; } \\
\text { duration } \mathcal{~ y e a r s ~}\end{array}$ \\
\hline & Dialysis-dependent CKD: NCT02174731 & $\begin{array}{l}\text { Phase III safety, efficacy and cardiovascular } \\
\text { outcome study; } 1,425 \text { patients on HD or PD; } \\
\text { event-driven up to } 2 \text { years; active } \\
\text { comparator epoetin alfa }\end{array}$ \\
\hline
\end{tabular}




\begin{tabular}{|c|c|c|}
\hline Compound (sponsor) & Trials registered with ClinicalTrials.gov ${ }^{*}$ & Study characteristics \\
\hline & $\begin{array}{l}\text { Dialysis-dependent CKD: NCT02273726 (active, } \\
\text { not yet recruiting) }\end{array}$ & $\begin{array}{l}\text { Phase III safety and efficacy study; } 1,200 \\
\text { patients on HD or PD; duration } 52 \text { weeks; } \\
\text { active comparator epoetin alfa }\end{array}$ \\
\hline & $\begin{array}{l}\text { Dialysis-dependent CKD: NCT02278341 } \\
\text { (Pyrenees) }\end{array}$ & $\begin{array}{l}\text { Phase III safety and efficacy study; } 750 \\
\text { patients on PD or HD; duration } 104 \text { weeks; } \\
\text { active comparator epoetin alfa or } \\
\text { darbepoetin alfa }\end{array}$ \\
\hline & $\begin{array}{l}\text { Dialysis-dependent CKD: NCT02052310 } \\
\text { (Himalayas) }\end{array}$ & $\begin{array}{l}\text { Phase III safety and efficacy study; } 750 \\
\text { patients on newly initiated HD or newly } \\
\text { initiated PD; maximum duration } 3 \text { years; } \\
\text { active comparator epoetin alfa }\end{array}$ \\
\hline \multirow[t]{5}{*}{ GSK1278863 (GlaxoSmithKline) } & Healthy individuals: NCT02293148 & $\begin{array}{l}\text { Pharmacokinetic study to evaluate effects on } \\
\text { cardiac repolarization }\end{array}$ \\
\hline & Nondialysis-dependent CKD: NCT01977573 & $\begin{array}{l}\text { Phase II safety and efficacy study; dosing for } \\
24 \text { weeks }\end{array}$ \\
\hline & Dialysis-dependent CKD: NCT02243306 & Pharmacokinetic study in patients on PD \\
\hline & $\begin{array}{l}\text { Dialysis-dependent CKD: NCT01977482 (not yet } \\
\text { recruiting) }\end{array}$ & $\begin{array}{l}\text { Phase II safety and efficacy study in patients } \\
\text { who switch from rhEPO; } 176 \text { patients; } \\
\text { dosing for } 24 \text { weeks; active comparator } \\
\text { placebo for } 4 \text { weeks followed by rhEPO }\end{array}$ \\
\hline & Dialysis-dependent CKD: NCT02075463 & $\begin{array}{l}\text { Phase II safety and efficacy study; } 20 \\
\text { patients on HD who are chronically hypo- } \\
\text { responsive to rhEPO therapy; duration } 16 \\
\text { weeks. }\end{array}$ \\
\hline JTZ-951 (Akros Pharma Inc.) & $\begin{array}{l}\text { Dialysis-dependent CKD: NCT01978587, } \\
\text { NCT01971164 (both studies completed) }\end{array}$ & $\begin{array}{l}\text { Phase I safety and tolerability study, } \\
\text { pharmacokinetic and pharmacodynamic } \\
\text { study; patients with ESRD and anaemia on } \\
\text { HD }\end{array}$ \\
\hline
\end{tabular}

$*$

Trials are currently active and/or enrolling unless noted otherwise; updated 2 January 2015. Additional information can be found in company websites. ${ }^{204-206}$ Abbreviations: CKD, chronic kidney disease; EPO, erythropoietin; ESA, erythropoietin-stimulating agent; ESRD, end-stage renal disease; HD, haemodialysis; HIF, hypoxia-inducible factor; PD, peritoneal dialysis; rhEPO, recombinant human EPO. 